\title{
Diversity and Versatility of Plant Seed Xyloglucan
}

\author{
植物種子由来キシログルカンの多様性と汎用性
}

\author{
Urakawa, Hiroshi ${ }^{1}$; Mimura, Mitsuru ${ }^{1}$; Kajiwara, Kanji ${ }^{2}$ \\ ${ }^{1}$ Faculty of Engineering and Design, Kyoto Institute of Technolgy, Sakyo-ku, Kyoto, 606-8585 Japan \\ ${ }^{2}$ Faculty of Home Economics, Otsuma Women's University, Chiyoda-ku, Tokyo, 102-8357 Japan \\ FAX: +81-3-5275-6932, E-mail: kajiwara@kk.chem.kit.ac.jp
}

Key Words: xyloglcan, tamarind seed, detarium, small-angle X-ray scattering, light scattering

\begin{abstract}
We demonstrate the diversity and versatility of plant seed xyloglucan by taking the examples of xyloglucans from the seed of Tamarindus indica and of Detarium senegalense Gmelin. The primary structure of plant seed xyloglucans is similar being composed of cellulose backbone. The flour obtained from Tamarindus indica and Detarium senegalense Gmelin seeds is consumed daily as a food additive but it is reported that those two xyloglucans reveal different physiological effects on the human body. Three types of monomers are available for xyloglucan. Thus the physiological function may be due to the higher order structure, which is specified by the sequence of different monomer types.

Light scattering and small-angle X-ray scattering is the major tool for investigating the structure of xyloglucan in solution. We will introduce briefly the methodology for the structural analysis of xyloglucan in solution. The analyzed results of light scattering and small-angle $\mathrm{X}$-ray scattering indicate that Detarium senegalense Gmelin has a branched structure whereas Tamarindus indica consists essentially of linear polysaccharide.
\end{abstract}

要 約

植物種子由来キシログルカンの多様性と沉用性を、 Tamarindus indica と Detarium senegalense Gmelin を例にとって 総説する。植物種子由来キシログルカンは、いずれもセルロー 久骨格で構成される同様な一次構造をもっている。Tamarindus indica と Detarium senegalense Gmelin 種子粉末は食品添加剂と して日常的に食されているが、私たちの体に及ぼす生理的効果 は植物種により異なる。キシログルカンのモノマー単位は 3 夕 イプある。従ってキシログルカンの生理的機能は、異なるモノ マーの並び方によって決まる高次構造に依存すると考えられ る。

光散乱と小角 $\mathrm{X}$ 線散乱は、キシログルカンの溶液中の構造 を調べる有力な手段である。まずキシログルカンの溶液中の構 造を調べる方法について述べる。光散乱と小角 $\mathrm{X}$ 線散乱の解析 結果は、Tamarindus indica は本質的に直鎖状多糖であるのに反 し、Detarium senegalense Gmelin は分岐構造をもっている可能性 を示唆する。

\section{A. Introduction}

Xyloglucan is a general term applied to non-starch plant polysaccharides composed of a $(1 \rightarrow 4)-\beta$-D-glucan spine (cellulose spine) with $(1 \rightarrow 6)$ - $\alpha$-branched xylose, which is partially substituted by $(1 \rightarrow 2)-\beta$-galacto-xylose (1). Xyloglucan is normally contained in plant seed, and its flour has been traditionally used as a food additive in everyday life in various products. Three types of monomer units are allocated to xyloglucan as shown in Fig. 1. Those units (heptasaccharide $\mathrm{DP}=7$, octasaccharide $\mathrm{DP}=8$ and nonasaccharide $\mathrm{DP}=9$ where $\mathrm{DP}$ denotes the number of residues) are composed of a sequence of four $(1 \rightarrow 4)-\beta$-D-glucans but differ in the number of galactose side chains (1).

Tamarind seed and detarium seed are typical examples used in everyday life in the preparation of soups and other baked
A. はじめに

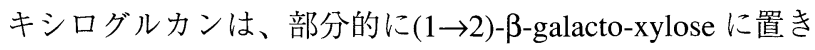

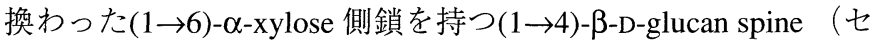
ルロース骨格）より構成される非澱粉植物多糖の総称である (1)。キシログルカンは通常植物種子に含まれており、その粉は 世界各地で伝統的な料理用に日常的に使われてきた。キシログ ルカンのモノマー単位としては、図 1 に示すように 3 つのタイ プがある。これらのモノマー単位、7量体（ $\mathrm{DP}=7 ） 、 8$ 量体 （DP=8）、9 量体（DP=9）、 DPは糖残基数を示す）は、いず

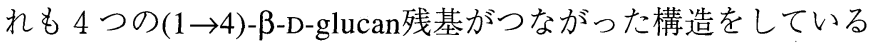
が、ガラクトース側鎖の数が異なる $(1)$ 。

タマリンド種子とデタリウム種子は濃いスープやいろいろ な焼き料理を作るのに日常的に使われている例で、いずれの種 


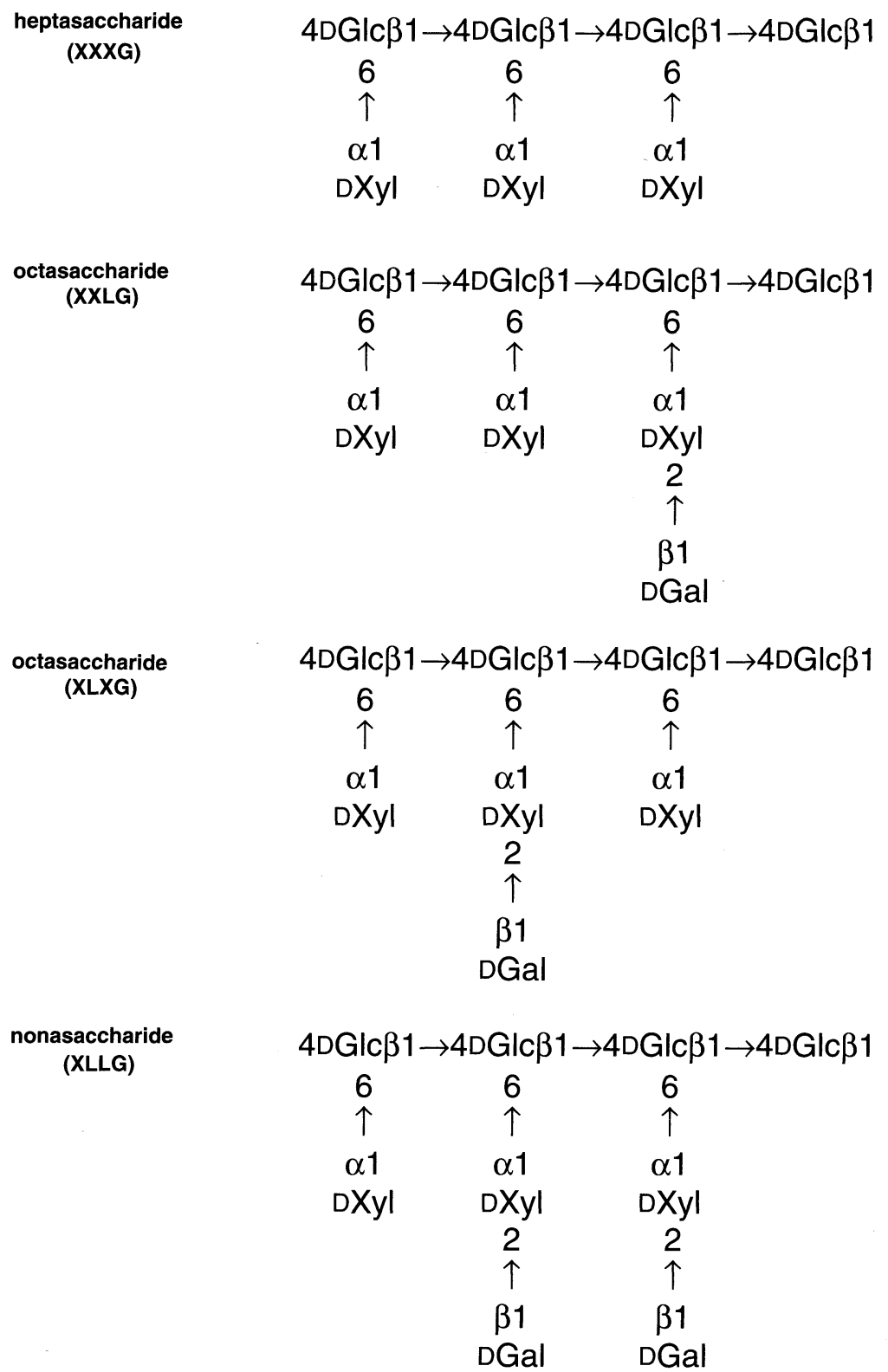

Fig. 1. Three types of monomer units of TSP xyloglucan.

Table I. Fraction of 4 oligosaccharide units in Tamarind Seed (TSP) and Detarium xyloglucan.

\begin{tabular}{|l|c|c|c|c|}
\hline Sample & XXXG & XLXG & XXLG & XLLG \\
\hline TSP & 1.00 & 0.42 & 2.08 & 6.20 \\
\hline Detarium & 1.00 & 0.30 & 5.60 & 6.20 \\
\hline
\end{tabular}

See Fig. 1 for the oligosaccharide units.

goods, as those plant seeds contain a high content of structurally similar xyloglucan, except that the content of galactose with respect to xylose and glucose is somewhat lower (2) in TSP (tamarind seed polysaccharide) xyloglucan (see Table I). TSP xyloglucan is stored in the seed of Tamarindus indica distributed widely in south-east Asia, while Detarium seed (Detarium
子も構造的には類似のキシログルカンが高度に含まれており、 その違いはキシロースやグルコースに比較してタマリンド種子 キシログルカン中のガラクトース含量が少し少ないだけである (2)(表 I 参照)。タマリンド種子キシログルカンは、東南アジア に広く分布する Tamarindus indicaの種子に貯蔵され、一方デ夕 


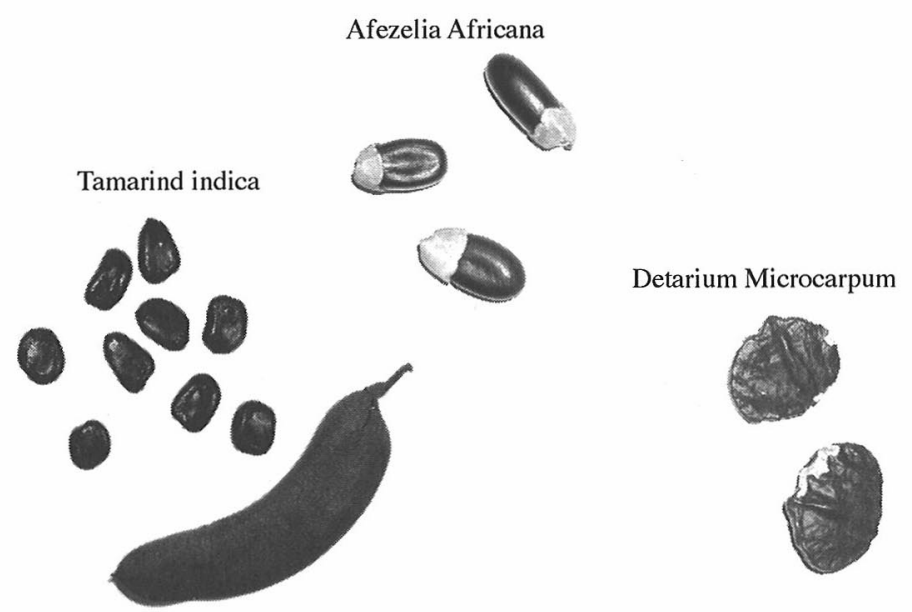

Fig. 2. Seeds of Tamarindus indica, Detarium senegalense Gmelin, and Afzelia Africana.

senegalense Gmelin) flour has been known as a traditional soup thickener used in everyday life in Nigeria. Afzelia Africana and Jatoba are other examples of food xyloglucans. These seeds (shown in Fig. 2) are available in the food markets in the respective countries, and are processed at home to make a thick broth. Xyloglucan normally dissolves in water, yielding high viscous solution, where gelation is prevented by the steric hindrance and hydrophilicity of $(1 \rightarrow 2)$ - $\beta$-galacto-xylose branches. Thus the elimination of galactose units induces gelation of xyloglucan aqueous solution.

Detarium xyloglucan is said to have significant nutritional and therapeutic benefits in the treatment of metabolic disorders and reduces the postcibal rise in blood glucose and insulin concentrations (3) as shown in Fig.3, whereas no such benefit was so far reported for tamarind seed polysaccharide (TSP).

Here a prime interest is to clarify whether and/or how the primary or higher-order structure of xyloglucan is correlated with its physiological function. A first step towards the prime interest will be the understanding of the dilute solution properties of xyloglucans. The conformation of an isolated native TSP xyloglucan is less understood, although it is conjectured to assume an extended zigzag chain from the analogy of cellulose (3). Native TSP xyloglucan shows a strong tendency for lateral aggregation in aqueous solution and the chain stiffness depends on the number of aggregated strands (4). An attempt has been made to elucidate the intrinsic properties of TSP xyloglucan by derivatization as this practice has been proved to be effective in the case of cellulose. The derivatization (the enzymatic oxidation) of native TSP xyloglucan introduces electrical charges onto TSP xyloglucan and is expected to improve its solubility in water.

In this report, we summarize the attempt for the molecular characterization of xyloglucans including gels, and discuss the potential versatility of xyloglucan applications.
リウム種子(Detarium senegalense Gmelin)の粉はナイジェリアの伝 統的な常食スープの増粘剤として知られている。食用キシログ ルカンとしてはその他 Afzelia Africana や Jatoba が知られている。 これらの種子(図 2 に示す)はそれぞれの国の市場で売られてお り、家庭内で濃いスープに調理されている。キシログルカンは

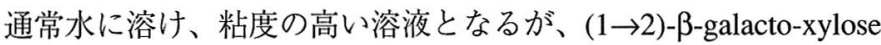
側鎖の立体障害と親水性のためゲル化はしない。つまりガラク トース残基を除去すればキシログルカン水溶液はゲル化する。

デタリウムキシログルカンは代謝異常治療において栄養上ま た治療上の効果が認められて扔り、図 3 に示すように食後の血 中グルコースやインシュリン濃度増加を抑える効果があるが、 タマリンド種子キシログルカンにはそのような効果は報告され ていない。

ここで最も興味を引かれるのは、キシログルカンの一次構造 あるいは高次構造がその生理活性と関連があるのか、あるとす ればどのように関連しているのか、を明らかにすることである う。このためにはまずキシログルカンの希薄溶液物性を理解す る必要がある。天然キシログルカン孤立鎖の形態はあまり分 かっていない。ただセルロースから類推して、ジグザグに伸び きっていると考えられている(3)。天然のタマリンドキシログル カンは水溶液中では鎖方向に並んだまま会合しており、鎖の固 さは会合した鎖の数に依る(4)。セルロースの場合に行われたよ うに、酵素酸化により天然キシログルカン誘導体を調製し、そ の孤立鎖の特性解明が試みられている。天然キシログルカンを 酵素酸化すると電荷をもつカルボキシル基が導入され、水への 溶解性が向上すると期待される。

本報告では、キシログルカン応用の沉用性を視野に入れて、 ゲルを含むキシログルカンの分子特性解明の試みを概説する。 

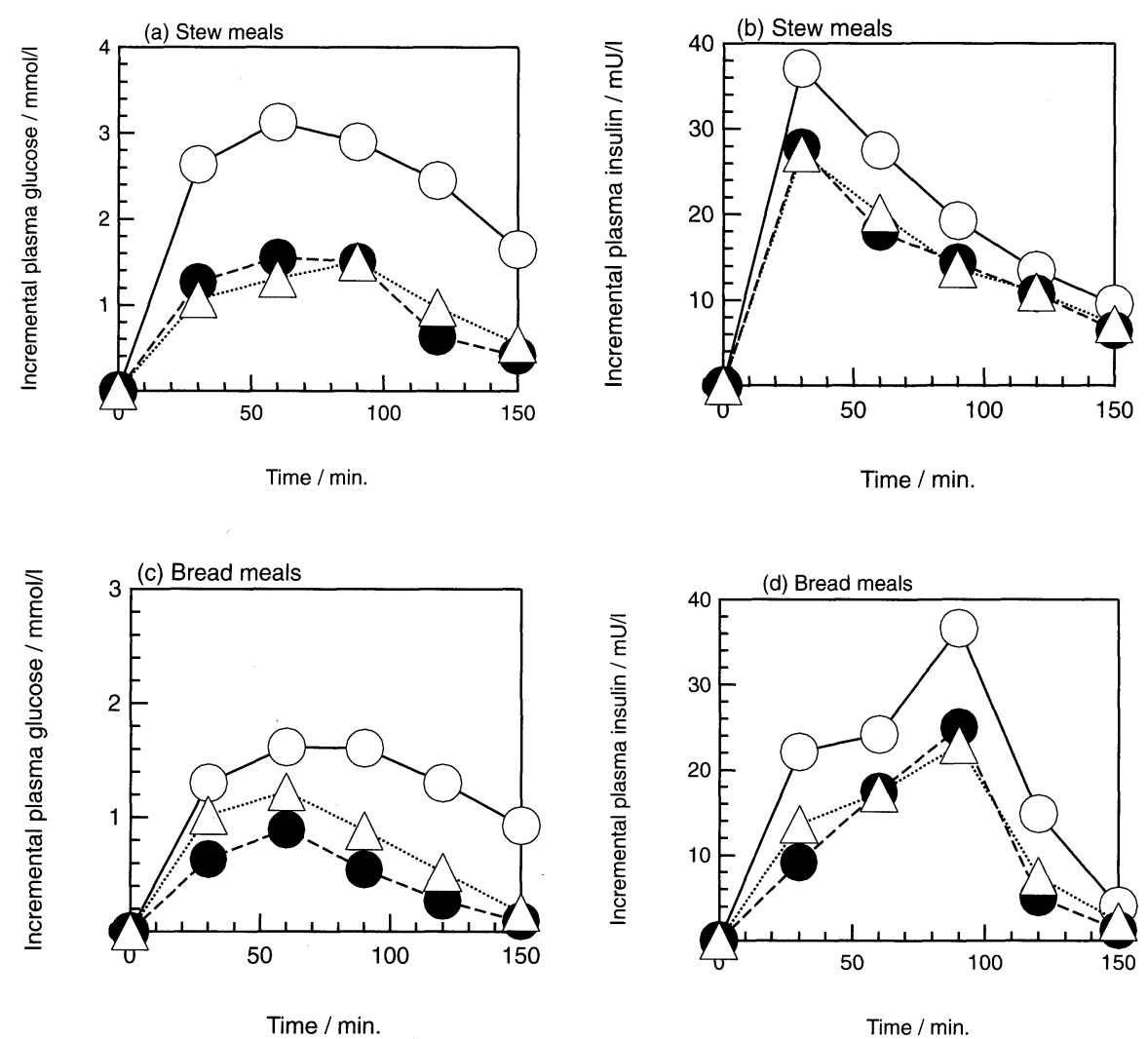

Fig. 3. Nutritional effect of Detarium senegalense Gmelin.

\section{B. Strategy for Molecular Characterization of Xyloglucans \\ - Electromagnetic Scattering and Computer Simulation}

Our strategy for molecular characterization of xyloglucans is (1) the application of electromagnetic scattering (including both light scattering and small-angle $\mathrm{X}$-ray scattering) to observe the intact chain structure in solution in the distance range from 10 to $20,000 \AA$, and (2) the preparation of good water-soluble xyloglucans by oligomerization or chemical modificatin.

The structure of polysaccharides in aqueous solution is neither completely ordered nor disordered. Thus polysaccharide is generally regarded as a semi-flexible polymer chain, and its conformation has been analyzed in terms of a semi-flexible chain model such as a helical wormlike chain(5) or a brokenrod chain(6). Experimental difficulty is mainly due to the nature of polysaccharides, which tend to aggregate as applied to food additives as a viscosity intensifier or gelling agent. In order to characterize the intrinsic property of polysaccharide chains, the polysaccharide chains should be molecularly dispersed in aqueous solution, but the solution was often not carefully prepared. In consequence the results so far reported contradicted each other. Although the semi-flexible polymer chain model describes consistently the dilute solution behavior of polysaccharide chains, the model would not afford to provide information
B. キシログルカン分子特性解明方法：電磁波散乱とコンピュー ターシミュレーション

キシログルカンの分子特性解明の戦略として、(1)オリゴ マー化あるいは化学修飾により易水溶性キシログルカンを調製 し、(2)電磁波散乱（光散乱及び小角 $\mathrm{X}$ 線散乱を組み合わせ る）により、溶液中の糖鎖構造をそのままの状態で 10 から 20,000 ̊̊の距離の範囲で観察する。

水溶液中における糖鎖は、完全な秩序構造でもなく、また 完全な無秩序構造でもない。そのため糖鎖は通常半屈曲性高分 子鎖モデル(螺旋ミミズモデル (5) や折れ曲がり棒モデル (6) )と して解析されてきた。実験的な困難さは主として会合しやすい という糖鎖の本質に由来する。糖鎖の固有の特性を解明するた めには、糖鎖は分子分散状態で水溶液中にあることが必要であ るが、溶液調製に十分な注意が払われてきたとはいい難い。そ のためこれまで報告されている実験結果がしばしば矛盾してい ることがあった。半屈曲性高分子鎖モデルは糖鎖の希薄溶液挙 
on precise local structure, which is considered to be the key to understanding the mechanism of the physiological function or gelation of polysaccharide chains.

Many polysaccharide chains are constituted of a series of locally ordered structures linked probably by random coil, and this locally ordered structure is considered to be responsible for gelation and other physiological functions of polysaccharides. The distance order of the locally ordered structure is around 30 to $200 \AA$, and is covered by the observation range of small-angle X-ray scattering (SAXS). Light scattering (LS) is suitable to observe the structure at the distance order of 5,000 to $20,000 \AA$, so that a combination of LS and SAXS will yield the structural information of polysaccharide in solution in the range from 10 to $20,000 \AA$ covering from the quasi-atomic level to a whole chain structure, although there is a missing gap between $500 \AA$ and 5,000 ̊. The scattering profile contains in principle all structural information, but the conventional analysis of the scattering profile yields only the statistical averages of the chain size specified by the radius of gyration and/or the cross-sectional radius of gyration. Here we employ the molecular dynamics to generate polysaccharide chains, and calculate directly the scattering profile of generated chains to compare with the observed scattering profile. If the calculated and observed scattering profiles are consistent, we may expect the generated chain reflects the structure of a real chain, and visualize the chain structure in solution from the computer-generated chains.

\section{Experimental Procedure Sample Preparation}

TSP xyloglucan (tamarind seed polysaccharide xyloglucan, commercially available as Glyloid from Dainippon Pharmaceutical, Osaka, Japan) was isolated from the seed kernels of Tamarindus indica, and was dissolved in water by stirring at room temperature. The solution was then centrifuged for 15 minutes at 8,000 rpm to remove insoluble ingredients. Isopropanol was added drop by drop to the supernatant up to a isopropanol concentration of $70 \%$. The precipitant was separated by centrifugation at $8,000 \mathrm{rpm}$ for 10 minutes, washed by $70 \%$ isopropanol aqueous solution, and dried in a vacuum at $500^{\circ} \mathrm{C}$ for $24 \mathrm{hrs}$.

TSP xyloglucan monomers (heptasaccharide, octasaccharide and nonasaccharide) were prepared from tamarind seed xyloglucan, according to the modification procedure proposed by York et al.(1). TSP xyloglucan was purified by precipitation from its aqueous solution into 2-propanol and dried with acetone in air prior to enzymatic hydrolysis. Purified xyloglucan $(1 \mathrm{~g})$ was dissolved in $100 \mathrm{ml}$ of $20 \mathrm{mM}$ sodium acetate buffer ( $\mathrm{pH} 4.0)$ and incubated at $37^{\circ} \mathrm{C}$ for 65 hours with $16 \mathrm{mg}$ end-1,4- $\beta$-glucanase from Trichoderma viride (Cellulase Onozuka 3S, Yakult Pharmaceutical Ind. Co. Ltd.). The reaction mixture was heated at $95^{\circ} \mathrm{C}$ for $20 \mathrm{~min}$ to inactivate the
動をよく説明するが、生理活性発現やゲル化機構を理解する鍵 となる精密な局所構造については何の情報も与えてくれない。

多くの糖鎖は、局所的な秩序構造をもつ部分が、多分無秩 序コイルで結ばれたと考えるのが妥当で、この局所的な秩序構 造部分がゲル化や生理活性発現に寄与していると考えられる。 局所的な秩序構造の距離は 30 から $200 \AA$ 程度であり、これは ちょうど小角X線散乱の観測範囲に入る。光散乱は 5,000 から 20,000 ̊̊程度の距離のオーダーの構造を観察するのに適してお り、光散乱と小角 $\mathrm{X}$ 線散乱を組み合わせると、500 から 5,000 ̊の範囲は欠けるものの、準原子レベルから鎖全体までの糖鎖 構造に関する情報が得られることになる。散乱プロファイルは 原理的にすべての構造情報を含んでいるはずだが、散乱プロ ファイルの通常の解析では慣性半径や断面の慣性半径といった 鎖サイズの統計平均を求めるにとどまっている。ここでは分子 動力学法を用いて糖鎖を発生し、発生した糖鎖から直接散乱プ ロファイルを計算する。もし計算散乱プロファイルが観察され た散乱プロファイルと一致すれば、計算機に発生させた糖鎖は 実際の糖鎖の構造を反映すると考えられ、糖鎖構造を計算機で 発生した糖鎖により視覚化することができる。

\section{C. 実験手法}

\section{試料調製}

$$
\text { タマリンドキシログルカン（大日本製薬よりグリロイドの }
$$

商品名で市販されている）は Tamarindus indicaの種子から抽出 し、室温で攪拌しながら水に溶かした。溶液を 15 分間 $8,000 \mathrm{rpm}$ で遠心し、不溶分を取り除いた。濃度が 70\%になるまでイソプ ロパノールを上澄み液に滴下し、沈殿物を 10 分室温で遠心して 分離、 $70 \%$ イソプロパノール水溶液で洗浄後 24 時間真空乾燥し た。

タマリンドキシログルカンモノマー（ 7 量体、 8 量体、 9 量体）はY York らの方法(1)に従ってタマリンドキシログルカン より調製した。タマリンドキシログルカンは水溶液をイソプロ パノールに落として沈殿させ、アセトンで風乾した後酵素分解 に供した。精製したキシログルカン（1 g）を $20 \mathrm{mM}$ 酢酸ナト リウムバッファー（pH4.0）100 mlに溶かし、16 mgの end-1,4$\beta$-glucanase（Trichoderma viride 由来、ヤクルト製薬製）を加え 37 度で 65 時間加温した。反応混合物を 20 分間 95 度に昇温し、 
enzyme and centrifuged at $8000 \mathrm{rpm}$ for $15 \mathrm{~min}$ to remove insoluble materials. The supernatant was passed through an ionexchange resin (SK1B, SA10A, Mitsubishi Chemical Co.), concentrated to a small volume with a rotary evaporator, and then freeze-dried. The mixture of oligosaccharide was separated by HPLC as follows: The mixture of three types of monomers $(0.6$ g) was dissolved in $6 \mathrm{ml}$ of distilled water and applied at room temperature to HPLC coupled with a preparation column YMC Pack Polyamine II (20 mmI.D. x 250mm, YMC Co. Ltd., Japan) and an RI detector. The flow rate was $8.0 \mathrm{ml} / \mathrm{min}$ with $50 \%$ acetonitorile as the eluent. Each monomer fraction was collected and rechromatographed on the same column.

Xyloglucan dimer which is constituted of an arbitrary combination of two monomers (DP of 14 to 18) was prepared from partial hydrolysis of xyloglucan.10\% xyloglucan aqueous solution was adjusted to $\mathrm{pH} 3.7$ by citric acid and incubated at $37^{\circ} \mathrm{C}$ for 64 hours with $0.4 \%$ end-1,4- $\beta$-glucanase. The reaction mixture was heated at $95^{\circ} \mathrm{C}$ for $20 \mathrm{~min}$ to inactivate the enzyme and centrifuged at $8000 \mathrm{rpm}$ for $15 \mathrm{~min}$ to remove insoluble materials. The supernatant was passed through an ion-exchange resin (SK1B, SA10A). The solution was precipitated by $60 \% 2-$ propanol and centrifuged at $3000 \mathrm{rpm}$ for $5 \mathrm{~min}$ to collect the precipitate. The precipitate was washed by $60 \% 2$-propanol and dried with acetone in air. The product was dissolved in distilled water (10\%), precipitated by $70 \%$ methanol and then centrifuged at $3000 \mathrm{rpm}$ for $5 \mathrm{~min}$ to remove insoluble materials. The supernatant was precipitated by $90 \%$ methanol and then centrifuged at $3000 \mathrm{rpm}$ for $5 \mathrm{~min}$ to collect the precipitate. The precipitate was washed by $90 \%$ methanol and dried with acetone in air. The content of xyloglucan dimer was analyzed at $60^{\circ} \mathrm{C}$ by HPLC coupled with columns Shodex SUGAR KS805 and KS 802 (8mmI.D. x 500mm, Showa Denko, Japan) and an RI detector. The flow rate was $1 \mathrm{ml} / \mathrm{min}$ with water as the eluent. The content was about $85 \%$.

Detarium senegalense Gmelin, the seed flour of an African leguminous plant, was provided by courtesy of Professor S. B. Ross-Murphy, King's College. When the subunits of xyloglucan are represented by 4 oligosaccharide units as XXXG, XLXG, XXLG and XLLG (Fig. 1), detarium xyloglucan and tamarind seed polysaccharide (TSP) are quantitatively analyzed
酵素を失活した後、8,000 rpm で 15 分間遠心して不溶分を除去 した。上澄み液をイオン交換カラム（SK1B, SA10A、三菱化学 製）に通し、回転式蒸発器で濃縮し、凍結乾燥した。オリゴ糖 の混合物は次の手順で HPLCで分離した。3タイプのモノマー $(0.6 \mathrm{~g})$ を $6 \mathrm{ml}$ の蒸留水に溶かし、室温で調製カラム YMC Pack Polyamine II と屈折率ディテクターを備えた HPLCに供し た。流出速度は毎分 $8 \mathrm{ml}$ で、溶離液は $50 \%$ アセトニトリル水 溶液を用いた。各モノマーを分取後、再度同じカラムにかけ精 製した。

キシログルカンダイマーは 2 つタイプのモノマーの任意 の組み合わせ（DP14 から 18）で構成されるが、キシログルカ ンの部分加水分解により調製した、 $10 \%$ のキシログルカン水溶 液をクエン酸で $\mathrm{pH} 3.7$ に調製し、0.4\% end-1,4-ß-glucanase を加 えて 37 度 64 時間加温した。反応混合物を 20 分間 95 度に昇温 し、酵素を失活させた後、8,000 rpm で 15 分間遠心して不溶分 を除去した。上澄み液をイオン交換カラム（SK1B, SA10A、三 菱化学製）に通し，溶出液を $60 \%$ イソプロパノールで沈殿させ、 沈殿物を $60 \%$ イソプロパノールで洗浄後、アセトンで風乾し た。生成物を濃度 $10 \%$ 程度になるよう蒸留水に溶かし、70\%メ タノールに沈殿し、3,000 rpm で5 分間遠心して不溶分を除去し た。上澄み液を $90 \%$ メタールで沈殿させ、 $300 \mathrm{rpm}$ で 5 分間 遠心して沈殿物を回収した。沈殿物は $90 \%$ メタノールで洗浄 後、アセトンで風乾した。キシログルカンダイマー含量は、60 度で Shodex SUGAR KS805 と KS 802カラム及び屈折率ディテッ クターを備えた HPLCで分析したところ、約 $85 \%$ であった。流 速は毎分 $1 \mathrm{ml}$ で、溶離液は水を用いた。

Detarium senegalense Gmelin（アフリカ産マメ科直物の種子 粉末）は、キングスカレッジ・ロスマーフィー教授の好意で提 供を受けた。キシログルカンの構成要素は 4 つのオリゴ糖単位 XXXG，XLXG，XXLG，XLLGで表される(図1)が、デタリ ウムキシログルカンとタマリンドキシログルカンはそれぞれの

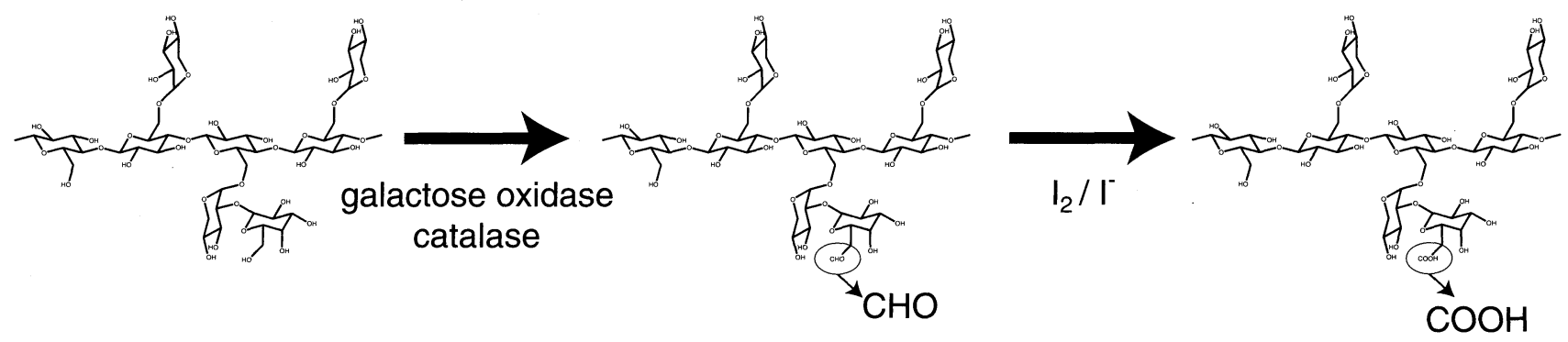

Fig. 4. Reaction scheme of the enzymatic oxidation. 
to contain those oligosaccharide units in the ratio of $1.00: 0.30$ $: 5.60: 6.20$ and $1.00: 0.42: 2.08: 6.20$, respectively (see Table 1). That is, the degree of galactose substitution of the xyloglucan core is lower in detarium xyloglucan than tamarind seed polysaccharide (TSP).

Carboxylated xyloglucan derivatives were prepared by enzymatic oxidation. The reaction scheme is shown in Fig. 4. Here the degree of oxidation was $83 \%$ in oxidized detarium xyloglucan, while three different degrees of oxidation were prepared from TSP xyloglucan, varying from $20 \%, 50 \%$ to $80 \%$.

\section{Static and Dynamic Light Scattering}

Static light scattering was observed from the aqueous solutions of xyloglucans and modified xyloglucans with and without the presence of salt at $20^{\circ} \mathrm{C}$ with a modified SOFICA photogoniometer (Baur Instrumentenbau, Hausen, Germany) in the angular range from $30^{\circ}$ to $150^{\circ}$ in $5^{\circ}$ steps. An argon ion laser was employed for a light source where $\lambda_{0}=488 \mathrm{~nm}$, and toluene was used as a primary standard. The refractive index increment $\mathrm{dn} / \mathrm{dc}$ was measured at $\lambda_{0}=436 \mathrm{~nm}$ by a Brice-Phoenix differential refractometer. $\mathrm{dn} / \mathrm{dc}=0.1583 \mathrm{ml} \cdot \mathrm{g}^{-1}$ for carboxylated detarium in $0.1 \mathrm{M} \mathrm{NaCl}$ aqueous solution.

Solutions for light scattering were prepared by dissolving a proper amount of carboxylated xyloglucan into $0.1 \mathrm{M} \mathrm{NaCl}$ aqueous solution or water, respectively. 8 solutions with various concentrations were prepared receptively by serially diluting the stock solutions with solvents. Each solution was filtered through $0.45 \mathrm{~mm}$ Millipore syringe filters. The weight-average molecular weight $M_{w}$, the z-average radius of gyration $R_{G}$ and the second virial coefficient $A_{2}$ were evaluated by the conventional Berry plots.

Dynamic light scattering measurements were performed with an ALV Spectrometer. The same solutions were used as the static light scattering measurements, and the results were analyzed by the quadratic cumulant fitting. The obtained $z$-average diffusion constants $D_{z}$ were converted into the hydrodynamic radius $R_{H}$ by the Stokes-Einstein equation:

$$
R_{H}=k T /\left(6 \pi \eta_{s} D_{z}\right)
$$

Here $\eta_{s}$ denotes the viscosity of solvent.

\section{Small-Angle X-ray Scattering}

Small-angle X-ray scattering (SAXS) was observed with SAXS equipment for solutions installed at BL-10C in the Photon Factory, Tsukuba, Japan. An incident beam from synchrotron radiation was monochromatized to $1=0.140 \mathrm{~nm}$ with a double-crystal monochorometer and focused to the position of the sample cell $1 \mathrm{~cm} \times 0.5 \mathrm{~cm} \times 0.2 \mathrm{~cm}$ (made of glass with quartz windows $20 \mathrm{~mm}$ thick) with a bent focusing mirror. The scattered X-ray was monitored by a one-dimensional position sensitive proportional counter (effective length $190 \mathrm{~mm}$ ) posi-
オリゴ糖単位を構成比にして $1.00: 0.30 ： 5.60 ： 6.20$ 及び 1.00 ：

$0.42: 2.08: 6.20$ 含んでいる(表 1 参照)。つまり、キシログルカ ン骨格に対するガラクトース残基の含量がタマリンドのほうが 低い。

カルボキシル化キシログルカン誘導体は酵素酸化により調 製した。反応スキームは図 4 に示す。デタリウムキシログルカ ンの酸化度は $83 \%$ 、タマリンドキシログルカンでは酸化度 20 \%、50\%、80\%のものを調製した。

\section{動的・静的光散乱}

キシログルカンおよび化学修飾したキシログルカン水溶液 （添加塩あり及びなし）からの静的光散乱は、改良型 SOFICA フォトゴニオメターを用いて散乱角 $30^{\circ}$ から $150^{\circ}$ まで $5^{\circ}$ 間 隔で観察した。測定温度は 20 度である。光源は波長 $488 \mathrm{~nm}$ の アルゴンイオンレーザーを用い、トルエンを光学系標準として 用いた。屈折率増加は Brice-Phoenix 型示差屈折系を用いて波長 $435 \mathrm{~nm}$ で測定した。カルボキシル化デタリウムキシログルカン $0.1 \mathrm{M} \mathrm{NaCl}$ 水溶液では $\mathrm{dn} / \mathrm{dc}=0.1583 \mathrm{ml} \cdot \mathrm{g}^{-1}$ であった。重量平均 分子量、 $\mathrm{z}$ 平均慣性半径、第 2 ビリアル係数は静的光散乱の結果 から通常のベリープロットから求まる。

動的光散乱はALV スペクトロメータを用いて観察した。静 的光散乱と同じ溶液を使用し、結果は 2 次式キュームラント フィッティングで解析した。得られる $\mathrm{z}$ 平均拡散係数 $\mathrm{D}_{\mathrm{z}}$ は Stokes-Einstein 方程式

$$
R_{H}=k T /\left(6 \pi \eta_{s} D_{z}\right)
$$

を用いて流体力学的半径 $R_{\mathrm{H}}$ に換算した。ここで $\eta_{s}$ は溶媒粘度 である。

慣性半径と流体力学的半径の比として定義される $\rho$ 值は高 分子鎖全体の構造を知る目安となり、例えば棒状高分子は $\rho>$ 2、ガウス鎖は $\rho \sim 1.4$ から 1.7、分岐高分子場合は $\rho \sim 0.8$ から 1.3、コンパクトな粒状高分子では $\rho<1.0$ となる。

\section{小角 $X$ 線散乱}

小角 $\mathrm{X}$ 線散乱（SAXS）はつくば市フォトンファクトリー BL10C の溶液用小角X線散乱装置で観察した。シンクロトロン 放射からの入射光は 2 重結晶モノクロメータで波長 $0.140 \mathrm{~nm}$ に 単波長化し、試料セル $(1 \mathrm{~cm} \times 0.5 \mathrm{~cm} \times 0.2 \mathrm{~cm})$ の位置にミラー を用いて焦点を合わせた。散乱した X 線強度は試料ホルダーか ら約 1 メートルの位置に取り付けた 1 次元 PSPC（有効長 190 
tioned at a distance of about 1 meter from the sample holder. The exact camera length was calibrated by the diffraction peaks of collagen fiber. The observed range was from $q=0.2 \mathrm{~nm}^{-1}$ to $q$ $=4.5 \mathrm{~nm}^{-1}$ in terms of the magnitude of scattering vector $q$ (三 $(4 \pi / \lambda) \sin (\theta / 2)$ with $\lambda$ and $\theta$ being the wavelength of the incident beam and the scattering angle, respectively).

The conventional analysis of the SAXS profiles yields the radius of gyration $R_{G}$ or the cross-sectional radius of gyration $R_{G c}$ from the slope of the linear part when plotted $\ln I(q)$ (the Guinier plot) or In $q I(q)$ (the cross-sectional Guinier plot) against $q^{2}$, respectively.

\section{Molecular Dynamics}

Three types of monomer units were computer generated (heptasaccharide, octasaccharide and nonasaccharide), and the molecular dynamics was applied to each generated monomer chain.

The particle scattering factor was calculated from the atomic coordinates of each simulated xyloglucan oligomer according to the Debye formula, that is, the scattering profile is given by

$$
I(q)-\sum_{i=1}^{n} g_{i}^{2} \phi_{i}^{2}(q)+2 \sum_{i=1}^{n-1} \sum_{j=i+1}^{n} g_{i} g_{j} \phi_{i}(q) \phi_{j}(q) \cdot \frac{\sin d_{i j} q}{d_{i j} q}
$$

where $q$ denotes the magnitude of a scattering vector given by $(4 \pi / \lambda) \sin \theta$ with $\theta$ and $\lambda$ being half the scattering angle and the wavelength of an incident X-ray, respectively. $g_{i}$ is an atomic scattering factor and $d_{i j}$ is the distance between the $i$ th and the $j$ th atoms. The form factor for the $i$ th atom $\phi_{i}(q)$ is assumed to be given by the form factor of a sphere having a radius equivalent to a van der Waals radius of the $i$ th atom as

$$
\phi_{i}(q)=\frac{3\left[\sin \left(R_{i} q\right)-\left(R_{i} q\right) \cos \left(R_{i} q\right)\right]}{\left(R_{i} q\right)^{3}}
$$

with $R_{i}$ being the van der Waals radius of the $i$ th atom:

\section{Dilute Solution Properties \\ Xyloglucan monomer}

The small-angle X-ray scattering (SAXS) is suitable for observing the structure of the distance order from 10 to $500 \AA$, which corresponds to the dimension of most oligomers. SAXS was observed from the aqueous solutions of heptasaccharide, octasaccharide and nonasaccharide of TSP xyloglucan monomer units at room temperature as shown in Fig. 5. The observed SAXS indicates the presence of aggregates in the aqueous solutions of heptasaccharide and octasaccharide as confirmed by the upturn of the scattered intensity at $q \rightarrow 0$ in the double logarithmic plots (not shown), while no such aggregation was observed in the aqueous solution of nonasaccharide. The lack of galactosic mm）で測定した。正確なカメラ長はコラーゲン瀻維の回折ピー クを利用して較正した。測定範囲は散乱ベクトル単位（q(三 $(4 \pi)$ ג) $\sin (\theta / 2))$ で $q=0.2 \mathrm{~nm}^{-1}$ から $q=4.5 \mathrm{~nm}^{-1}$ までであった。ここで $\lambda$ と $\theta$ はそれぞれ入射光の波長及び散乱角である。

通常のSAXS プロファイルの解析では、ギニエプロットや 断面のギニエプロットから慣性半径あるいは断面の慣性半径が 求まる。

\section{分子動力学}

コンピューターで 3 タイプのモノマー単位を発生させ、発 生したモノマー単位ごとに分子動力学法を適用した。

発生した各キシログルカンオリゴマー分子の原子座標か ら、粒子散乱因子を Debye の式

$I(q)^{-} \sum_{i=1}^{n} g_{i}^{2} \phi_{i}^{2}(q)+2 \sum_{i=1}^{n-1} \sum_{j=i+1}^{n} g_{i} g_{j} \phi_{i}(q) \phi_{j}(q) \cdot \frac{\sin d_{i j} q}{d_{i j} q}$

に従って計算した。ここで $g_{i}$ は原子散乱因子、 $d_{i j}$ は $\mathrm{i}$ 番目原 子と $\mathrm{j}$ 番目原子間の距離、 $\phi_{i}(q)$ は $\mathrm{i}$ 番目原子の形状因子である が、 $\mathrm{i}$ 番目原子の van der Waals 半径と同じ半径 $\mathrm{R}_{\mathrm{i}}$ の剛体球の形 状因子

$$
\phi_{i}(q)=\frac{3\left[\sin \left(R_{i} q\right)-\left(R_{i} q\right) \cos \left(R_{i} q\right)\right]}{\left(R_{i} q\right)^{3}}
$$

で与えられると仮定する。

\section{D. 希薄溶液物性}

キシログルカンモノマー

小角X線散乱（SAXS）は $10 \AA$ から $500 \AA ̊$ の距離のオーダー の構造を観察するのに適しており、その距離範囲はほとんどの オリゴマーの大きさに相応している。図 5 は、タマリンドキシ ログルカンのモノマーである 7 量体糖、8 量体糖、9 量体糖の 水溶液から観察されたSAXS プロファイルである。ここには示 さないが両対数プロットで散乱強度が散乱角度 0 に向かって立 ち上がることから、 7 量体糖と 8 量体糖の水溶液には会合体が 存在する。しかしそのような会合体は 9 量体糖の水溶液には見 

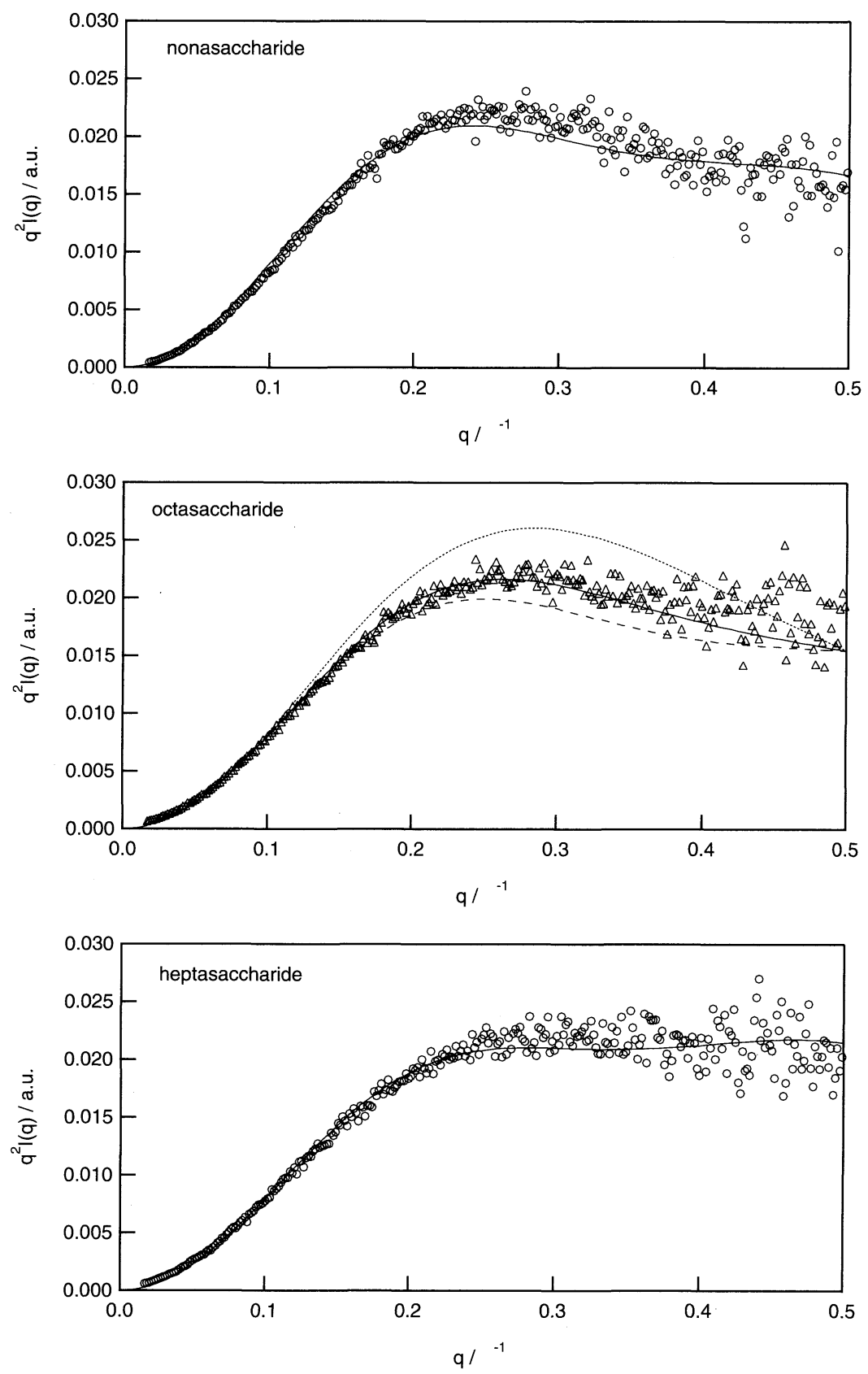

Fig. 5. Small-angle $X$-ray scattering observed (black circles) and calculated (solid or dotted lines) from three types of TSP xyloglucan monomer units (heptasaccharide, octasaccharide and nonasaccharide). Octasaccharide has two isomers, and the solid line represents the calculated profile as the average of those from the two isomers (30\% octasaccharide 1 and 70 $\%$ octasaccharide 2). The dotted lines correspond to the scattering profiles from the octasaccharide 1 (above) and the octasaccharide 2 (below). See Figs. 1 and 6 for the specification of the octasaccharides 1 and 2.

units seems to promote aggregation.

The observed SAXS profiles were analyzed conventionally to evaluate the radius of gyration $R_{G}$ and the cross-sectional radius of gyration $R_{G c}$ from the respective Guinier plots as summarized in Table 2. The effect of aggregation appears at lower $q$ range, so that the corresponding radius of gyration was evaluated from the linear portion in the respective Guinier plots satis-
られなかった。ガラクトース残基の欠如が会合を促進する。

観察されたSAXS プロファイルを通常の方法で解析して、 慣性半径及び断面の慣性半径を評価した（表 2 参照）。低角部 には会合の影響が残っているので、評価条件を満たす散乱角範 囲で対応するギニエプロットの直線部分から慣性半径を求め 
Table II. Radius of gyration $\boldsymbol{R}_{G}$, the cross-sectional radius of gyration $\boldsymbol{R}_{G c}$ and 3 semi-axes $a, b$ and $c$ of the model ellipsoid representing the shape of TSP xyloglucan heptasaccharide, octasaccharide and nonasaccharide.

\begin{tabular}{|c|c|c|c|}
\hline TSP xyloglucan & $R_{G} / \mathrm{nm}$ & $R_{G c} / \mathrm{nm}$ & $a \times b \times c / \mathrm{nm}^{3}$ \\
\hline \multicolumn{4}{|l|}{ TSP monomer } \\
\hline Heptasaccharide & $0.73^{\mathrm{a}}$ & $0.32^{\mathrm{b}}$ & $0.22^{\mathrm{d}} \times 0.62^{\mathrm{d}} \times 1.49^{\mathrm{d}}$ \\
\hline Octasaccharide & $0.72^{\mathrm{a}}$ & $0.37^{\mathrm{b}}$ & $0.22^{\mathrm{d}} \times 0.71^{\mathrm{d}} \times 1.43^{\mathrm{d}}$ \\
\hline Nonasaccharide & $0.72^{\mathrm{a}}$ & $0.39^{b}$ & $0.23^{\mathrm{d}} \times 0.75^{\mathrm{d}} \times 1.41^{\mathrm{d}}$ \\
\hline \multicolumn{4}{|l|}{ TSP dimer } \\
\hline $\mathrm{DP}=14 \sim 18$ & $1.12^{\mathrm{a}}$ & $0.36^{\mathrm{b}}$ & $0.22^{\mathrm{c}} \times 0.69^{\mathrm{d}} \times 2.40^{\mathrm{d}}$ \\
\hline \multicolumn{4}{|l|}{ TSP trimer } \\
\hline $\mathrm{DP}=21 \sim 27$ & $1.62^{\mathrm{a}}$ & $0.37^{\mathrm{b}}$ & $0.22^{\mathrm{e}} \times 0.75^{\mathrm{d}} \times 3.54^{\mathrm{d}}$ \\
\hline \multicolumn{4}{|l|}{ TSP tetramer } \\
\hline $\mathrm{DP}=28 \sim 36$ & - & $0.37^{\mathrm{b}}$ & - \\
\hline$(1 \rightarrow 4)$ - $\beta$-D-glucan & & & \\
\hline spine & - & 0.21 & - \\
\hline
\end{tabular}

${ }^{\text {a }}$ Estimated from the Guinier plots

${ }^{\mathrm{b}}$ Estimated from the Guinier plots for cross-section

${ }^{\mathrm{c}}$ Estimated from the Guinier plots for thickness

${ }^{\mathrm{d}}$ Calculated by assuming an ellipsoidal shape

${ }^{\mathrm{e}}$ Assumed

fying the condition that $q R_{G} \cong 1$ or $q R_{G c} \cong 1$. In order to avoid the ambiguity due to the narrow Guinier range for monomers, the tri-axial body fitting was examined for the observed SAXS profiles from TSP xyloglucan monomers. Each profile was found to be represented by an ellipsoid(7), whose dimensions are listed in Table II. The ellipsoid dimensions are consistent with the radius of gyration and the cross-sectional radius of gyration evaluated from the observed SAXS profiles, where $R_{G}{ }^{2}$ and $R_{G c}{ }^{2}$ are calculated as $\left(a^{2}+b^{2}+c^{2}\right) / 5$ and $\left(b^{2}+c^{2}\right) / 4$ from the model ellipsoids. The radius of gyration seems almost invariant with the molecular weight, although the cross-sectional radius of gyration (calculated) was found to increase slightly with the number of residues in side chains. The removal of galactose side chains causes thinning of the cross-section of TSP xyloglucan. The cross-sectional radius of gyration of xyloglucan monomers is considerably larger than that evaluated for $(1 \rightarrow 4)-\beta$-D-glucan spine $(0.21 \mathrm{~nm}$ for cellulose)(8), indicating the xylose or galactoxylose branches protruding from the spine. Another characteristic of the xyloglucan cross-section is its flatness. In the elliptic models fitted to each monomer, the length of the shortest semiaxis is constant at $0.22 \mathrm{~nm}$ for all three types of monomers. The width of the cross-section increases from $0.62 \mathrm{~nm}$ (heptasaccharide) to $0.71 \mathrm{~nm}$ (octasaccharide) and $0.75 \mathrm{~nm}$ (nonasaccharide) as the number of residues in side chains increases. The results indicate the side chains protruding horizontally from the flat $(1 \rightarrow 4)-\beta$-D-glucan spine surface. The longest axis may represent the spine length, which should be the same
た。次に直線部分が短いために起こるあいまいさを避けるため に、散乱プロファイル全体を 3 軸剛体モデルで合わせることを 試みた。3 軸モデルとしては棈円体が適当(7)で、そのディメン ジョンは表 II にまとめてある。楕円体から計算した慣性半径 $R_{G}{ }^{2}$ $=\left(a^{2}+b^{2}+c^{2}\right) / 5$ 及び断面の慣性半径 $R_{G c}{ }^{2}=\left(b^{2}+c^{2}\right) / 4$ の值は、ギニ エプロットから評価した慣性半径の值とよく一致する。慣性半 径は分子量に依存しないが、断面の慣性半径は側鎖の残基数が 増すと少し大きくなる傾向にある。ガラクトース側鎖の除去は キシログルカン断面を薄くする。キシログルカンモノマーの断 面の慣性半径は (1 $\rightarrow 4)$ - $\beta$-D-glucan 骨格（セルロースの場合は $0.21 \mathrm{~nm})(8)$ に比べてかなり大きく、キシロースやガラクトキ シロース側鎖が骨格から突き出ていることを示唆する。キシロ グルカン断面の他の特徴はその薄さにある。各モノマーに合わ せた楕円体の最短半軸はいずれも $0.22 \mathrm{~nm}$ と変わらなかった。 断面の幅は $0.62 \mathrm{~nm}$ ( 7 量体糖)から $0.71 \mathrm{~nm}$ ( 8 量体糖)、0.75 nm ( 9 量体糖) と側鎖残基数が増えるに従って増加する。最長軸は骨 格の長さに対応し、骨格の形態が同じなら 3 タイプのモノマー で変わらないはずである。実際は残基数が多いモノマーほど短 
among three types of monomers if the spine conformation is identical. However, a shorter length was found for a larger monomer, suggesting a more arched structure.

Three types of TSP xyloglucan monomers were simulated by molecular dynamics in order to elucidate the details of chain conformation. The particle scattering factors were calculated according to eq. (2) from the atomic coordinates of the
くなっており、骨格がより湾曲していることを示唆する。

より詳細な糖鎖形態を明らかにする目的で、3タイプのモ ノマーを分子動力学法でシミュレートした。図 6 にシミュレー トされたモノマー鎖を示すが、その原子座標から散乱関数を （2）式に従って計算した。結果は図 5 の曲線で示す。なお図 6

heptasaccharide(XXXG)
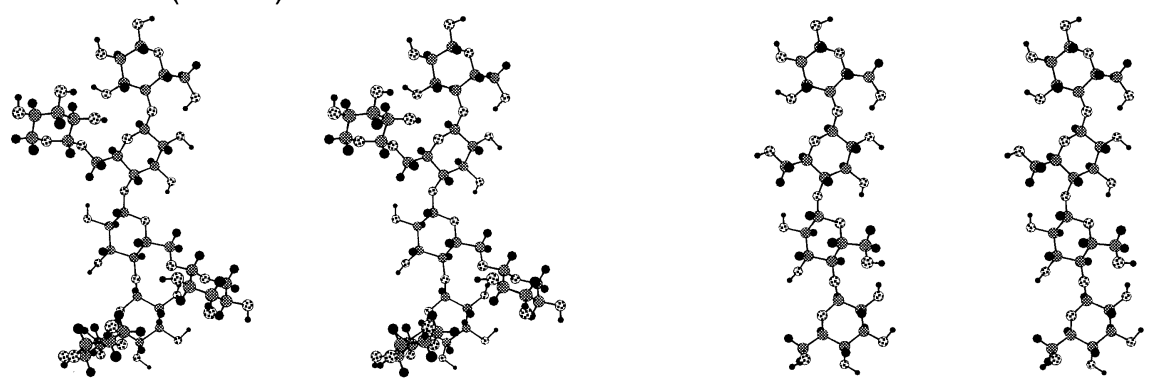

octasaccharide(XXLG)
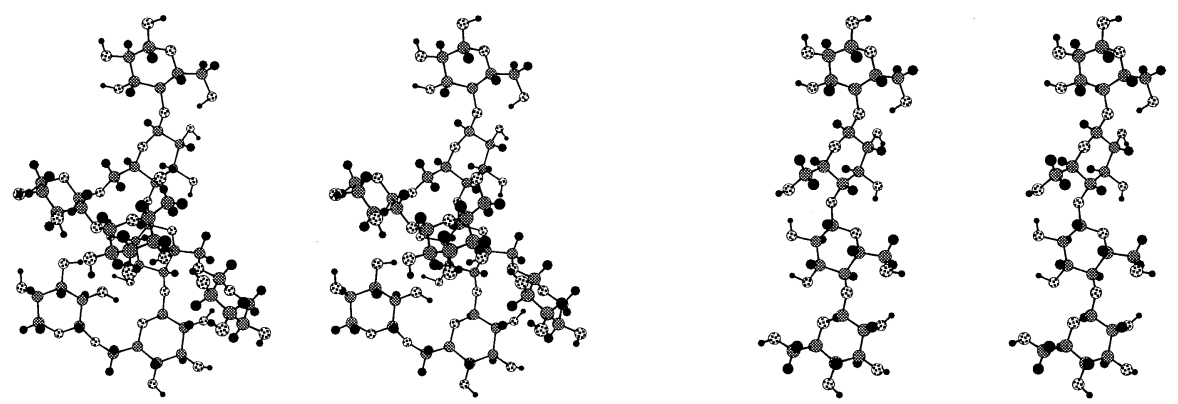

octasaccharide $(X L X G)$
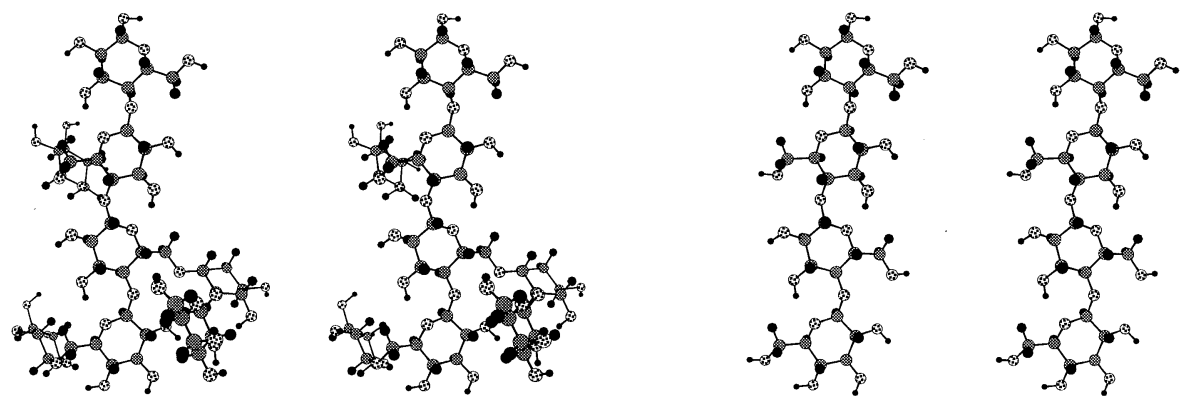

nonasaccharide(XLLG)
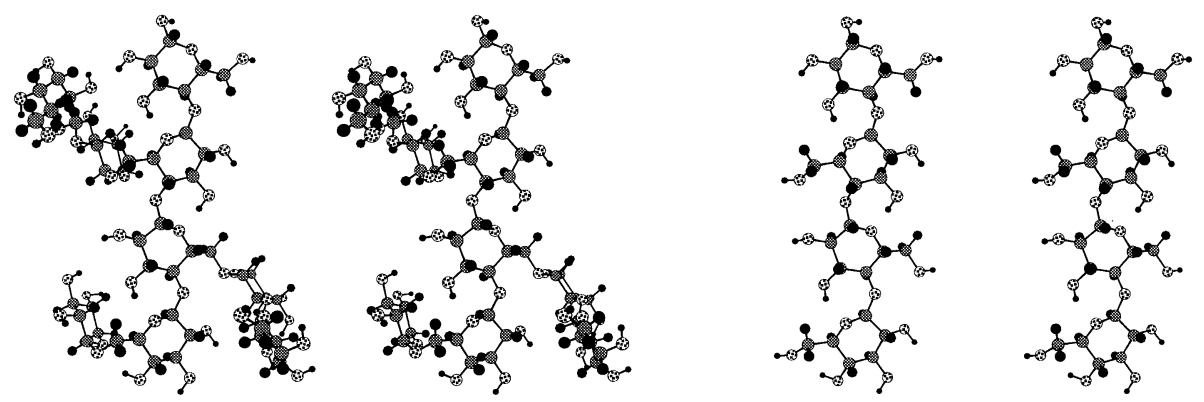

Fig. 6. Simulated TSP xyloglucan monomer units (stereo figure), and the corresponding $(1 \rightarrow 4)-\beta$-D-glucan spines of each TSP xyloglucan monomer (stereo figure). 
simulated xyloglucan monomer units schematically shown in Fig. 6. The results are shown in Fig. 5, where the solid lines show the calculated scattering profiles. The agreement with the observed SAXS profiles is satisfactory, so that the simulated chains represent the conformation of respective TSP xyloglucan monomer units in water. The simulated monomer units are shown in Fig. 6, where respective $(1 \rightarrow 4)-\beta$-D-glucan spines are also shown. Two isomers are available for TSP xyloglucan octasaccharide (also see Fig. 1). Both isomers were simulated and the corresponding scattering profiles were calculated. Since TSP xyloglucan octasaccharide consists of the mixtures of two isomers, the scattering profile was calculated as a weighted average (30:70 in this instance, see the caption for Fig. 5) of those scattered from two isomers in order to fit the observed SAXS profile. The dotted lines show the scattering profiles corresponding to respective octasaccharide isomers.

Here $(1 \rightarrow 4)-\beta$-D-glucan spines were found to assume a rather flat conformation, and xylose and galacto-xylose branches to extend and fold upright on the $(1 \rightarrow 4)-\beta$-D-glucan flat surface. The conformation is similar to the results by Levy et al.(9) who simulated the conformation of TSP xyloglucan side chains by assuming flat (cellulose-like) and twisted (cellobiose-like) backbone conformation. The twisted backbone conformation is supposed to be preferred in solution(9).

In order to elucidate the effect of xylose branches on the spine conformation, the expected scattering profiles from the $(1 \rightarrow 4)$ - $\beta$-D-glucan spine (cellulose spine) were calculated from the simulated TSP xyloglucan monomer units (see Fig. 7). The scattering profiles are slightly different from each other, reflecting the difference in the chain conformation. Nonasaccharide seems to have a flat arched spine conformation, while
には骨格部分のみ取り出した分子モデルも参考のために示す。 観察されたSAXS プロファイルとよく一致するところから、計 算機で発生したタマリンドキシログルカンモノマー鎖は実際の モノマー鎖の水中での形態をよく反映していると考えられる。 タマリンドキシログルカン 8 量体糖には 2 つの同位体がある （図1参照）。2つの同位体共にシミュレートし、実際の系で はこの 2 つ同位体が混ざっていることから、散乱関数は $30 ： 70$ の割合で混ざっているものと仮定して散乱関数を計算した。図 6 の点線はおのおのの同位体の散乱関数を示す。

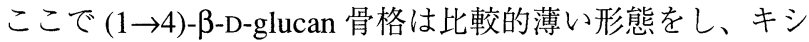
ロース側鎖及びガラクトキシロース側鎖はその薄い表面上に突 き出て、それからほぼ直角に折れ曲がっていることが分かる。 同様な形態は、セルロース類似の薄い形態とセロビオース類似 のねじれた形態を骨格の形態として仮定してタマリンドキシロ グルカンの形態をシミュレートしたLevy et al. (9)の結果と矛盾 しない。

$$
\text { キシロース側鎖が骨格の形態に及ぼす影響を見るために、 }
$$

骨格からの散乱プロファイルを図 7 に計算した。散乱関数はモ ノマータイプによる少し異なり、骨格形態が違うことを示唆す る。9 量体糖は薄い湾曲した骨格形態をとっているが、8 量体 糖、 7 量体糖は少しねじれた骨格形態をしている。ガラクトー 又残基の欠如が疎水性を增す結果となり、骨格を少しねじると

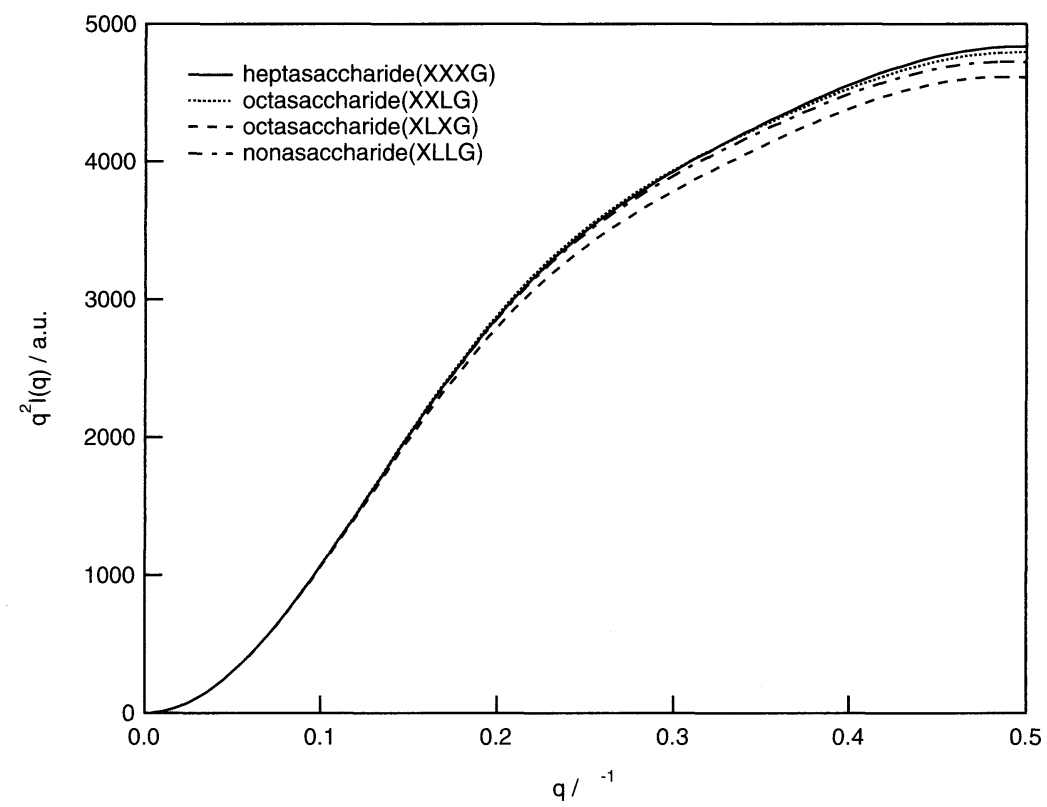

Fig. 7. Scattering profiles expected from the $(1 \rightarrow 4)$ - $\beta$-D-glucan spine (cellulose spine) of each TSP xyloglucan monomer unit. 

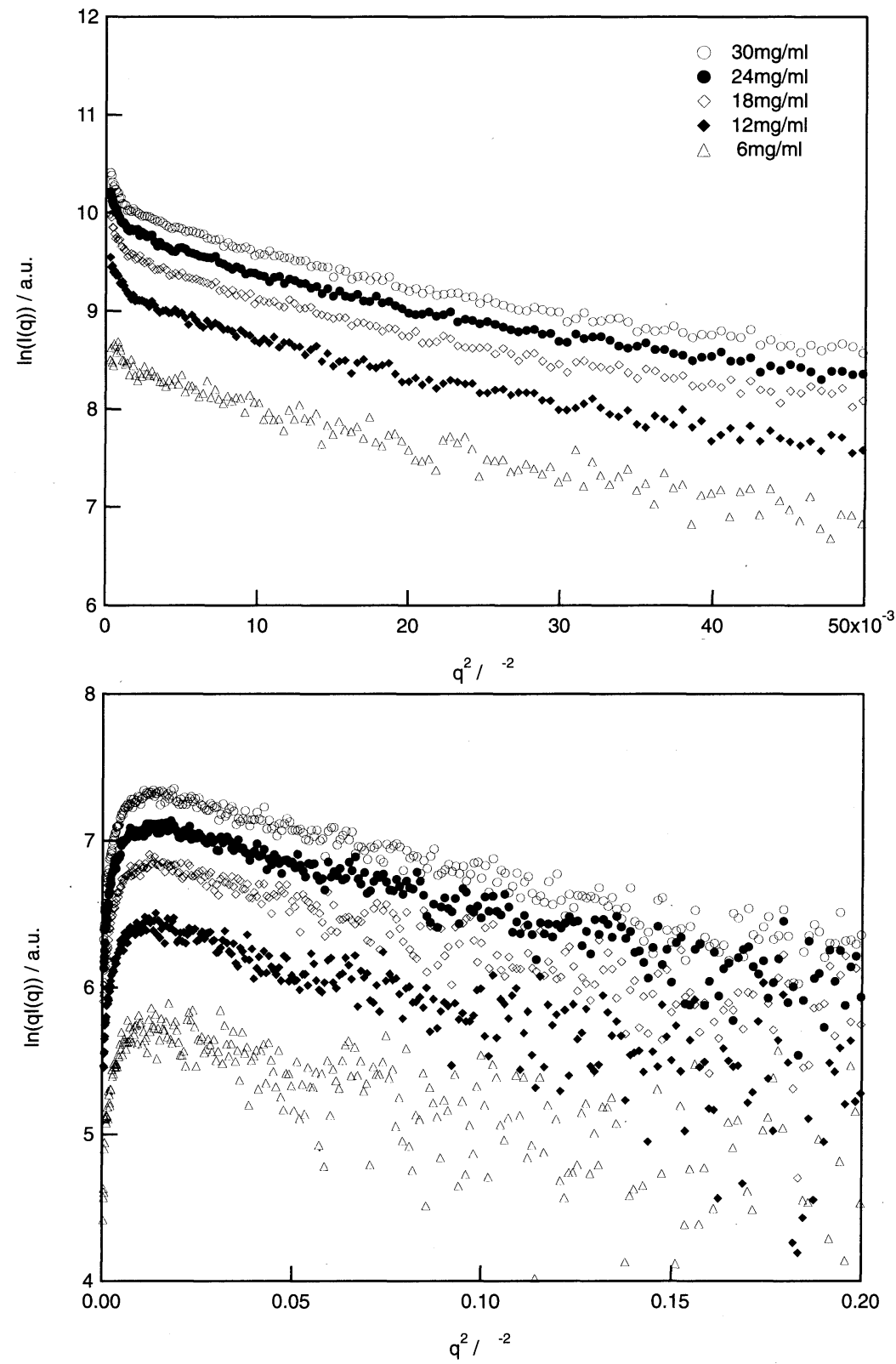

Fig. 8. SAXS profile observed from TSP xyloglucan dimer in aqueous solution (Guinier plots and cross-sectional Guinier plots).

octasaccharide and heptasaccharide assume a slightly twisted conformation. The loss of galactose side chains results in the increase of hydrophobicity and seems to twist the backbone.

\section{Xyloglucan dimer/trimer/tetramer}

The SAXS profile from TSP xyloglucan dimer shows considerable aggregation as shown in Fig. 8. The radius of gyration $R_{G}$ and the cross-sectional radius of gyration $R_{G c}$ were evaluated from the conventional Guinier plots ignoring the data at lower scattering angles as summarized in Table 2. Assuming an elliptic shape, the longest semi-axis is calculated as $2.40 \mathrm{~nm}$ from the values of two radii $R_{G}$ and $R_{G c}$ estimated from the re-
思われる。

キシログルカン 2 量体オリゴマー、3 量体オリゴマー、4 量体 オリゴマー

図 8 は夕マリンドキシログルカン 2 量体オリゴマーの SAXS プロファイルであるが、かなり会合している様子が伺え る。低角部のデー夕を無視して慣性半径、断面の慣性半径を通 常のギニエプロットで評価した結果を表 2 にまとめる。楕円体 を仮定して最長半軸を 2 つ慣性半径（慣性半径及び断面の慣 性半径）から計算すると $2.40 \mathrm{~nm}$ となる。断面の慣性半径はモ 
spective Guinier plots of observed SAXS intensities. The crosssectional radius of gyration is almost identical to those estimated for the monomers, but, due to the thin arched structure, the longest semi-axis length is shorter than the double of the longest semi-axis length estimated for monomers.

The cross-sectional radii of gyration of TSP xyloglucan trimer and tetramer are estimated as $0.39 \mathrm{~nm}$ and $0.37 \mathrm{~nm}$, respectively, from the cross-sectional Guinier plots (see Table 2). These values are identical to those estimated for TSP xyloglucan monomers and dimer. The results confirm the stiff nature of TSP xyloglucan, which has a thin ribbon-like structure. An elliptic shape was assumed for TSP xyloglucan trimer and the length of spine was estimated as $3.54 \mathrm{~nm}$ (Table 2) using the values of $R_{G}$ and $R_{G c}$ estimated from the respective Guinier plots of observed SAXS intensities. Although the value is not exactly equal to 3 times the monomer length, it seems that an additional monomer unit adds approximately $1 \mathrm{~nm}$ to the total length of the spine. This increase in the spine length per monomer unit is reasonable when considering the slightly arched flat $(1 \rightarrow 4)-\beta$-D-glucan spine structure.

\section{Xyloglucan polymers}

Dilute solution properties of plant seed xyloglucans (both Tamarindus indica and Detarium senegalense Gmelin) and the carboxylated derivatives were investigated by means of static/ dynamic light scattering and small-angle X-ray scattering (SAXS). The weight-average molecular weight $M_{w}$, the z-average radius of gyration $R_{G}$ and the second virial coefficient $A_{2}$ were evaluated by the conventional Berry plots from respective static light scattering data. The same solutions were used as the static light scattering measurements, and the results were analyzed by the quadratic cumulant fitting. The obtained $z$-average diffusion constants $D_{z}$ were evaluated by the quadratic cumulant fitting of the time correlation function observed by the dynamic light scattering, which were converted conventionally into the hydrodynamic radius $R_{H}$ by the Stokes-Einstein equation. The results were summarized in Table 3.

SAXS revealed that xyloglucan chains are stiff and the cross-sectional radius of gyration is around $0.5 \mathrm{~nm}$ regardless of the xyloglucan species. Here the cross-sectional radius of gyration was evaluated for TSP xyloglucan, detarium xyloglucan and carboxylated detarium xyloglucan as $0.58 \mathrm{~nm}, 0.49 \mathrm{~nm}$ and $0.48 \mathrm{~nm}$, respectively(11). The higher value observed for TSP xyloglucan is probably due to the lateral aggregation. The results are consistent with the light scattering observation on the carboxylated TSP xyloglucan, where the carboxylated TSP xyloglucan revealed high chain stiffness (the Kuhn length $l_{k} \geq$ $140 \mathrm{~nm}$ ), but 3 to 5 chains are still laterally aggregated as the evaluated values of the mass per unit length $M_{L}$ indicated(12). As the cross-sectional radius of gyration of xyloglucan polymers is almost identical to that evaluated from its oligomers, the
ノマー単位で評価した值とそれほど変わらない。しかし全体と しては薄い湾曲した形態をとるため、最長半軸の長さはモノ マー単位の值を 2 倍した值よりも短い。

$$
\text { タマリンドキシログルカン } 3 \text { 量体オリゴマー、 } 4 \text { 量体オリ }
$$

ゴマーの断面の慣性半径はそれぞれ $0.39 \mathrm{~nm} 、 0.37 \mathrm{~nm}$ であった

（表 2 参照）。この值はモノマー、2 量体オリゴマーの値とほ ぼ同じで、タマリンドキシログルカン鎖が比較的剛直であるこ とを確認する。3 量体オリゴマーに楕円体を仮定してその最長 半軸の長さを求めると $3.54 \mathrm{~nm}$ であった（表 2 ）。この值は正 確にモノマー単位の長さの 3 倍にはならないが、追加モノマー 単位一つに対し約 $1 \mathrm{~nm}$ 骨格の全体長が長くなる。この骨格長 のモノマー単位あたりの増加は薄い湾曲した $(1 \rightarrow 4)-\beta$-D-glucan 骨格構造を考えれば妥当であろう。

キシログルカンポリマー

植物種子由来のキシログルカン（Tamarindus indica と Detarium senegalense Gmelin）、及びそのカルボキシル化誘導体 の希薄溶液物性を動的・静的光散乱、小角 $\mathrm{X}$ 線散乱（SAXS） で調べた。重量平均分子量、 $\mathrm{z}$ 平均慣性半径、第 2 ビリアル係 数は静的光散乱の結果から通常のベリープロット評価した。同 じ溶液を使って動的光散乱より流体力学的半径を評価した。結 果は表 3 にまとめてある。

SAXS の結果は、キシログルカン鎖は剛直で、キシログルカ ン種に関係なくその断面の慣性半径は焼く $0.5 \mathrm{~nm}$ であった。夕 マリンドキシログルカン、デタリウムキシログルカン、カルボ キシル化デタリウムキシログルカンの断面の慣性半径はそれぞ れ $0.58 \mathrm{~nm} 、 0.49 \mathrm{~nm} 、 0.48 \mathrm{~nm}$ である(11)。タマリンドキシログ ルカンの值が大きいのは縦方向に会合しているためであろうと 考えられる。この結果はカルボキシル化タマリンドキシログル カンの光散乱結果と矛盾しない。光散乱の結果から、カルボキ シル化タマリンドキシログルカンは剛直（クーン長 $l_{k} \geq 140 \mathrm{~nm}$ ) で、3 から 5 つの鎖が縦方向に会合しているということが単位 長あたりの分子量の結果より示唆された (12)。断面の慣性半径 の值はキシログルカンオリゴマーの值とあまり変らないことか ら、キシログルカンの局所的な形態は、図 6 に示す分子モデル 
Table III. Molecular characteristics of detarium xyloglucan, carboxylated detarium and TSP xyloglucan observed by static/ dynamic light scattering and small-angle $X$-ray scattering.

\begin{tabular}{|lcccccc|}
\hline & $\begin{array}{c}c_{\mathrm{NaCl}} \\
(\mathrm{mol} / \mathrm{L})\end{array}$ & $\begin{array}{c}\mathrm{M}_{\mathrm{w}} \times 10^{-6} \\
(\mathrm{~g} / \mathrm{mol})\end{array}$ & $\begin{array}{c}\mathrm{A}_{2} \times 10^{4} \\
\left(\mathrm{~mol} \cdot \mathrm{ml} / \mathrm{g}^{2}\right)\end{array}$ & $\begin{array}{c}\mathrm{R}_{\mathrm{G}} \\
(\mathrm{nm})\end{array}$ & $\begin{array}{c}\mathrm{R}_{\mathrm{H}} \\
(\mathrm{nm})\end{array}$ & $\begin{array}{c}\rho \\
\left(\equiv \mathrm{R}_{\mathrm{G}} / \mathrm{R}_{\mathrm{H}}\right)\end{array}$ \\
\hline TSPOX20 & 0.1 & 1.47 & 1.6 & 123 & 75 & 1.64 \\
TSPOX50 & 0.1 & 0.85 & 2.4 & 83 & 55 & 1.51 \\
TSPOX80 & 0.1 & 5.0 & 3.6 & 61 & 45 & 1.36 \\
TSPOX80 & 0.01 & 0.79 & 3.8 & 95 & 58 & 1.98 \\
TSPOX80 & $10^{-3}$ & 0.56 & 4.0 & 71 & 41 & 1.73 \\
TSP & - & 1.16 & 7.0 & 122 & 78 & 1.56 \\
\hline DetariumOX & 0.1 & 0.462 & 0.253 & 66 & 69 & 0.96 \\
Detarium & - & 2.69 & 1.9 & 118 & - & - \\
\hline Gellan & 0.1 & 0.49 & 22.0 & 159 & 137 & 3.06 \\
Xanthan & 0.1 & 2.94 & 4.9 & 290 & 69 & 2.12 \\
\hline
\end{tabular}

OX denotes "oxidized", and the figure attached to OX denotes the degree of oxidation. The light scattering data for detarium xyloglucan was taken from Wang et al.(10)

local conformation of xyloglucan polymers is considered to be also represented by the simulated molecular models shown in Fig. 6.

The results of light scattering (summarized in Table III) from the aqueous solutions of detarium xyloglucan and its derivatives show a remarkable contrast to those of tamarind seed polysaccharide (TSP) and its derivatives. Although TSP has a similar primary structure as detarium xyloglucan, it exhibits a strong tendency for self-association. The same tendency for selfassociation was observed in the carboxylated derivative of TSP. The light scattering behavior from TSP and carboxylated TSP in aqueous solution is in accordance with the solution theory of a linear stiff chain, and yielded the $r$ value ranging from 1.51 to 1.56. Those $r$ values indicate a stretched linear architecture, and in fact the scattering profile was found to fit the profile calculated by assuming a stiff linear chain (the Kuhn segment length ranging from $108 \mathrm{~nm}$ to $184 \mathrm{~nm}$ ). The SAXS from the TSP aqueous solution showed good linearity in the cross-sectional Guinier plot as expected for a rod-like molecule, which estimated the cross-sectional radius gyration as $0.58 \mathrm{~nm}$. This large value of the cross-sectional radius of gyration is attributed to the multistranded lateral aggregates of TSP in aqueous solution.

The SAXS results from detarium contradict to some extent, the results obtained by static and dynamic light scattering. As mentioned above, the SAXS indicates a rod-like structure for detarium xyloglucan and carboxylated detarium xyloglucan where the cross-sectional radius of gyration was found to be similar among those samples. If detarium xyloglucan has an extended chain conformation represented by a stiff rod, the $\mathrm{r}$ value should be as large as 2 , or at least show the value just
オリゴマーの形態とほほ同じであると考えられる。

デタリウムキシログルカン及びその誘導体水溶液からの光 散乱の結果（表 III）はタマリンドキシログルカン及びその誘導 体の結果と著しく異なる。デタリウムもタマリンドもキシログ ルカンの一次構造はあまり変わらないが、タマリンドキシログ ルカンは自己会合しやすい。自己会合の傾向はカルボキシル化 タマリンドキシログルカンにも見られる。タマリンドキシログ ルカン及びカルボキシル化タマリンドキシログルカンの光散乱 挙動は半屈曲性線状高分子の溶液理論とよく一致し、 $\rho$ 值は 1.51 から 1.56 の範囲にある。この $\rho$ 值はタマリンドキシログルカン が比較的伸びた形態の線状高分子であることを示唆し、事実散 乱プロファイルはクーン長が $108 \mathrm{~nm}$ から $184 \mathrm{~nm}$ 位の固い高分 子と仮定して計算した散乱プロファイルとよく合う。タマリン ドキシログルカン溶液の SAXS も、棒状分子から期待される断 面のギニエプロットのよい直線性が観察され、断面の慣性半径 は $0.58 \mathrm{~nm}$ であった。この值は大きく、タマリンドキシログルカ ンは溶液中で複数の鎖が縦方向に会合していると考えられる。

デタリウム及びカルボキシル化デタリウムキシログルカン のSAXS 結果は、棒状であることを示唆し、断面の慣性半径も 他のキシログルカン試料とほぼ同じ值が得られている。もしデ タリウムキシログルカンも、一次構造が類似のタマリンドキシ ログルカンと同様に半屈曲性線状高分子として表せるなら、 $\rho$ 值は 2 、あるいは少なくとも 1.5 程度はあるはずである。光散 乱結果から評価したカルボキシル化タマリンドキシログルカン の $\rho$ 值は 0.96 であり、コンパクトな形態をしていることを示 


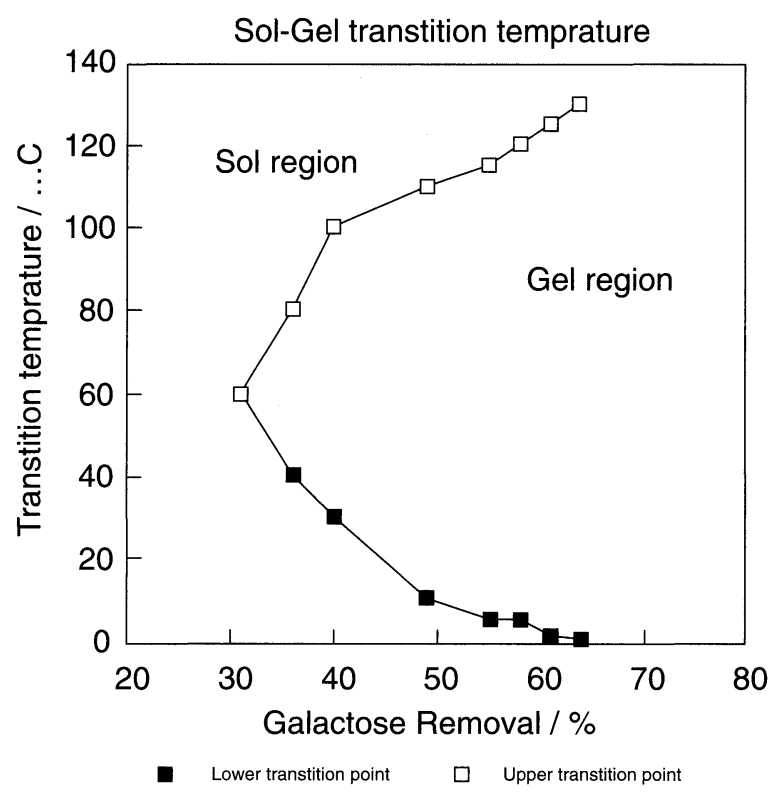

Fig. 9. Sol-gel transition temperature diagram of enzymatically degraded TSP xyloglucan.

above 1.5 as observed for tamarind seed polysaccharide (TSP) which has a similar primary structure. The $r$ value for carboxylated detarium was estimated as 0.96 (see Table 3), which indicates that enzymatically modified detarium xyloglucan has a branched architecture and the branching process may be characterized as being random. Although it is still a matter of further investigation whether the branched structure is associated to the physiological effects of detarium xyloglucan(3) or the branching is due to the enzymatic reaction, we may indicate that carboxylated detarium xyloglucan is composed of highly branched cores containing over 50 branch points with radiating long arms or tied with long linear chains.

\section{Suprastructure}

As gelation is prevented by the steric hindrance and hydrophilicity of $(1 \rightarrow 2)-\beta$-galacto-xylose branches, the enzymatic degradation by $\beta$-galactosidase results in the gelation of xyloglucan aqueous solution at room temperature when about $50 \%$ of galactose residues are released(13). As the loss of $(1 \rightarrow 2)$ $\beta$-galactose proceeds with reaction time, more aggregation takes place to form crosslinking domains. The resulting gel is opaque and has a unique property to melt at lower and higher temperatures as shown in Fig. 9.

The time-resolved small-angle scattering was observed from the $1 \%$ TSP xyloglucan solution undergoing enzymatic degradation where the $\beta$-galactosidase concentration was adjusted for gelation to take place after $1 \mathrm{hr}$ reaction. The scattering profile changes as the reaction proceeds (Fig. 10), where the profile at a higher $q$ region exhibits the characteristics of the rod-like scattering. Although no distinct sol-gel transition was
す。この結果を矛盾なく説明するためには、デタリウムキシロ グルカンが分岐構造をとっているとすれば良い。分岐化は他の 多糖で見られるように統計的に起こると考えられるが、分岐化 が天然に存在しているのか、酵素処理によるものかは現時点で は分からない。またデタリウムキシログルカンの生理活性が分 岐構造に起因しているかどうかは今後の研究に依るが(3)、光散 乱の結果から、デタリウムキシログルカンが高度に分岐したコ アから 50 本程度の長い線形鎖が放射状に伸びているか、あるい は統計的に高度に分岐したアミロペクチン状の構造をしている ことが示唆される。

\section{超構造}

$(1 \rightarrow 2)-\beta$-galacto-xylose 側鎖の立体障害と親水性がゲル化を 妨げているので、 $\beta$-galactosidaseによる酵素分解はガラクトース 残基が $50 \%$ ほど分解した時点で室温でキシログルカン水溶液の ゲル化を誘起する (13)。その結果白濁したゲルを形成するが、 このゲルは図 9 に示すように温度を下げても、また温度を上げ てもゾルになるというユニークな性質を持っている。

タマリンドキシログルカン $1 \%$ 溶液が酵素分解していく過 程を時分割小角X線散乱で観察した。ここで酵素（ $\beta$ galactosidase）濃度は一時間後にゲル化が起こるよう調節した。 散乱プロファイルは図 10 に示すように反応が進むに従って変化 するが、広角部分は変わらず棒状分子の散乱の特徵を示す。散 乱プロファアイルでは明確なゾル・ゲル転移は観察されないが、 クラトキープロット $\left(q^{2} I(q)\right.$ 対 $\left.q\right)$ では酵素反応が進むに従っ 

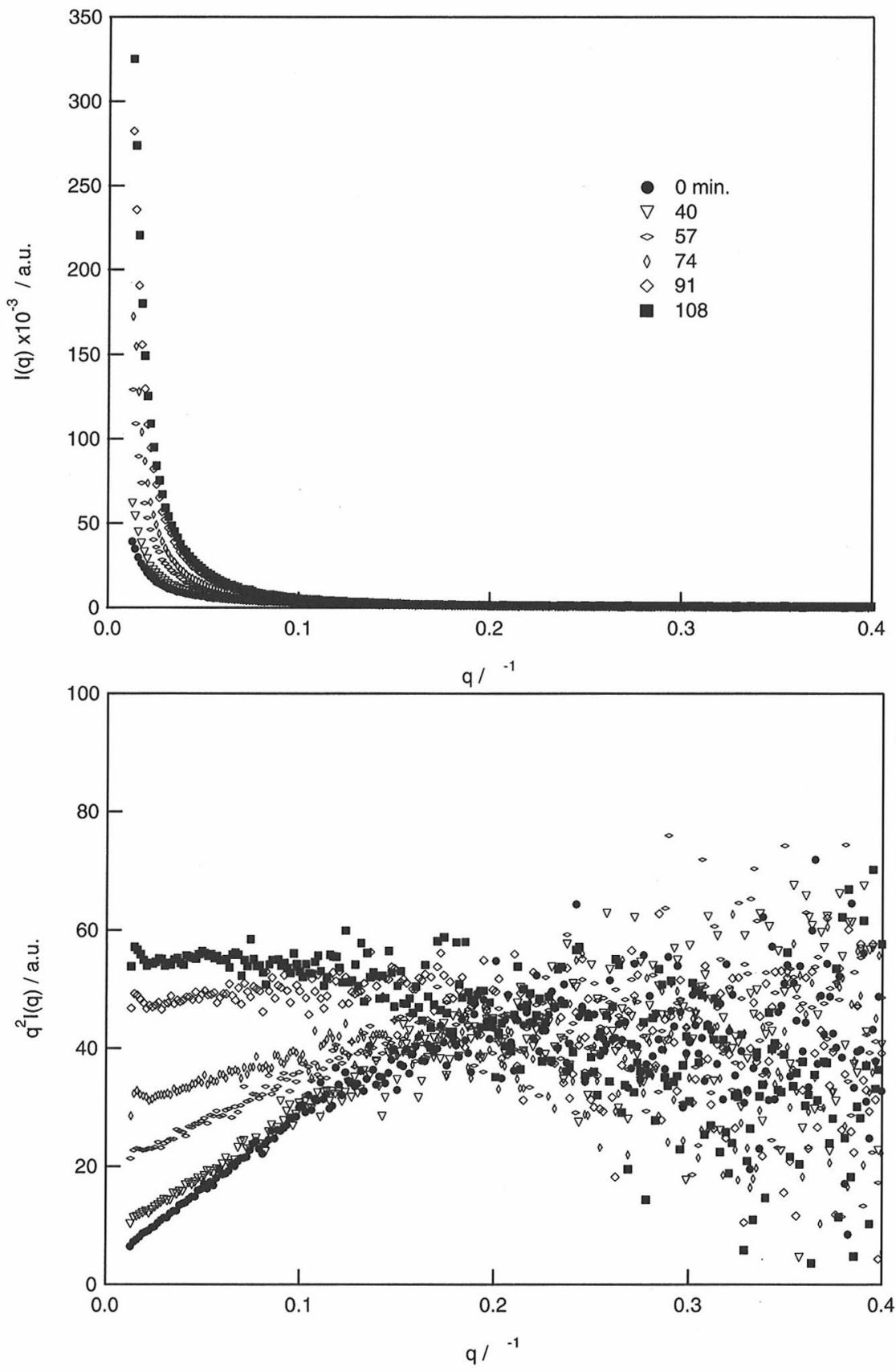

Fig. 10. Time-resolved small-angle scattering profile from the aqueous solution of enzymatically degrading TSP xyloglucan.

observed in the scattering profile, the Kratky plots $\left(q^{2} I(q)\right.$ plotted against $q$ ) show a marked change of the profile in the medium $q$ range while the enzymatic reaction progressed.

The conformation of xyloglucan side chains was simulated by assuming the flat (cellulose-like) and twisted (cellobiose-like) backbone conformation by Levy et al.(9), where the twisted backbone conformation is supposed to be preferred in solution. Since the conventional analysis of the SAXS scattering profiles suggested the formation of flat objects upon gelation(7), the aggregates induced by hydrophobic interaction are thought to have the shape of flat discs, which serve as the
て中角部分で顕著な変化が現れる。

セルロース類似の薄い形態とセロビオース類似のねじれた 形態を骨格の形態として仮定してタマリンドキシログルカンの 形態をシミュレートしたLevy et al. (9) の結果によると、溶液中 ではキシログルカン骨格はねじれた形態をとっている。この結 果を踏まえて、(1 $\rightarrow 4)-\beta$-D-glucan 40 残基で骨格を作り、部分的 に $(1 \rightarrow 2)-\beta$-galacto-xylose で置き換えた $(1 \rightarrow 6)-\alpha$-xylose 側鎖 30 分岐をつけたキシログルカンモデル鎖を構築した。SAXS プロ 


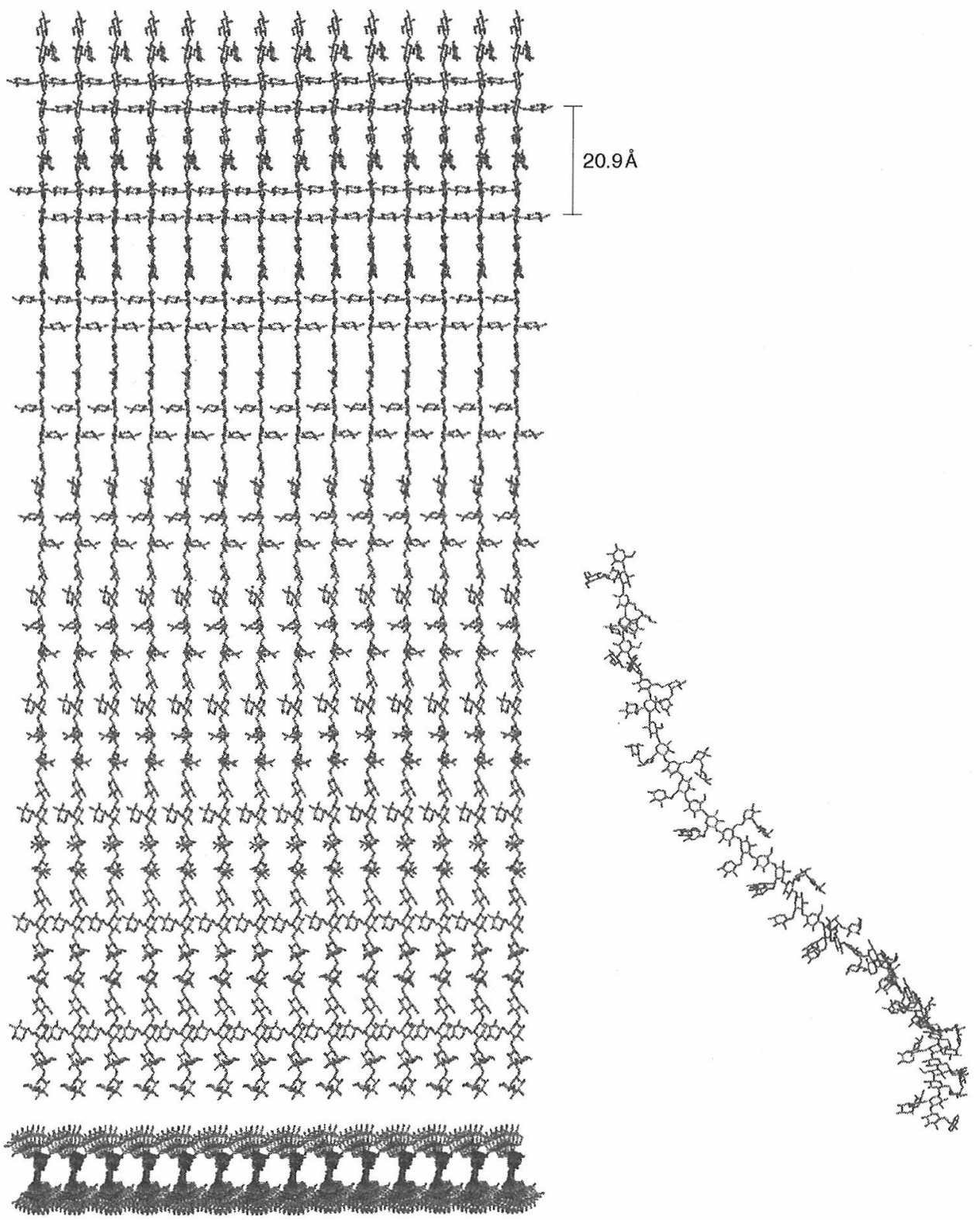

Fig. 11. Molecular model for TSP xyloglucan aggregate.

crosslinking domain. Thus the molecular model for the flat aggregates was constructed by stacking the cellulose -like backbones for simplicity. Here 14 xyloglucan chains (each composed of $40(1 \rightarrow 4)$ - $\beta$-D-glucans with $30(1 \rightarrow 6)$ - $\alpha$-xylose branches, which are partially substituted by $(1 \rightarrow 2)-\beta$-galacto-xylose $)$ are stacked to form a flat ordered aggregate (see Fig. 11), where the thickness is calculated as $1.1 \mathrm{~nm}$, almost identical to that evaluated by the Guinier plots for thickness from the observed SAXS profiles(7). The scattering profile from the TSP xyloglucan aggregate was calculated as shown in Fig. 12 from the atomic coordinates of the molecular model according to the Debye formula eq. (2).

A single chain of TSP xyloglucan composed of $40(1 \rightarrow 4)$ -
ファイルの通常の解析（厚みのギニエプロット）からは酵素反 応が進行しゲル化すると薄層会合体が形成されていることが分 かった(7)。疎水性相互作用により形成される会合体は平板な ディスクの形をしていると考えられ、この会合体が架橋ドメイ ンとなっている。この平板なディスクの分子モデルを、上で構 築したキシロースモデル鎖を規則的に 14 本並べた平板な会合モ デルを構築した（図 11 ）。この会合体の厚みは $1.1 \mathrm{~nm}$ で、こ の值は実測 SAXS プロファイルから求めた厚み (7) とほぼ同じ である。タマリンドキシログルカン会合体の、散乱プロファイ ルはデバイの式（2）に従って分子モデルの原子座標から計算 

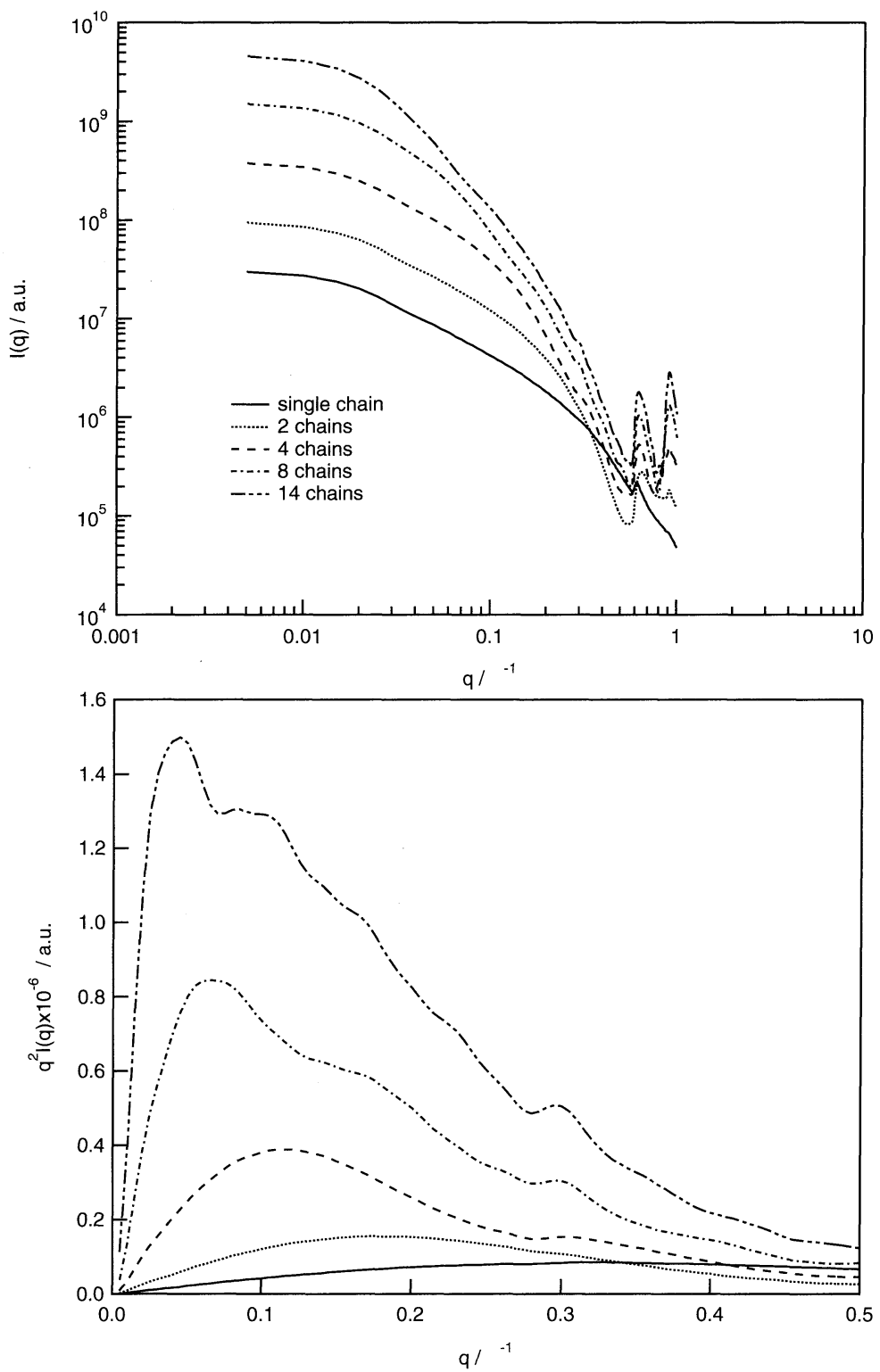

Fig. 12. Scattering profile from the model TSP xyloglucan single chain and aggregates. The number of aggregated chains is indicated in the figure.

$\beta$-D-glucans with $30(1 \rightarrow 6)$ - $\alpha$-xylose branches, which are partially substituted by $(1 \rightarrow 2)-\beta$-galacto-xylose, was built by assuming a flat cellulose-like $(1 \rightarrow 4)-\beta$-D-glucan spine conformation as granted, and its scattering profile (also shown in Fig. 12) was calculated as above.

Gelation is assumed to take place according to the classic Flory-Stockmayer polyfunctional polycondensation scheme(14). Here gel is tree-like and the scattering intensity from such a tree is calculated as(15)

$$
\begin{gathered}
I(q)=A^{2}(q)(1+\alpha \phi) /[1-(f-1) \alpha \phi] \\
\phi=\exp \left(-b^{2} q^{2} / 6\right)
\end{gathered}
$$

した（図 12）。キシログルカン一本鎖の散乱プロファイルも同 様に計算した（図 12）。

ゲル化は古典的なフローリー・ストックマイヤーの多官能 重縮合スキーム (14)に従うと仮定する。ゲルは樹木状になり、 このモデルからの散乱強度は

$$
\begin{gathered}
I(q)=A^{2}(q)(1+\alpha \phi) /[1-(f-1) \alpha \phi] \\
\phi=\exp \left(-b^{2} q^{2} / 6\right)
\end{gathered}
$$

で与えられる(15)。ここで $f$ は架橋ドメインの官能数（ドメ 


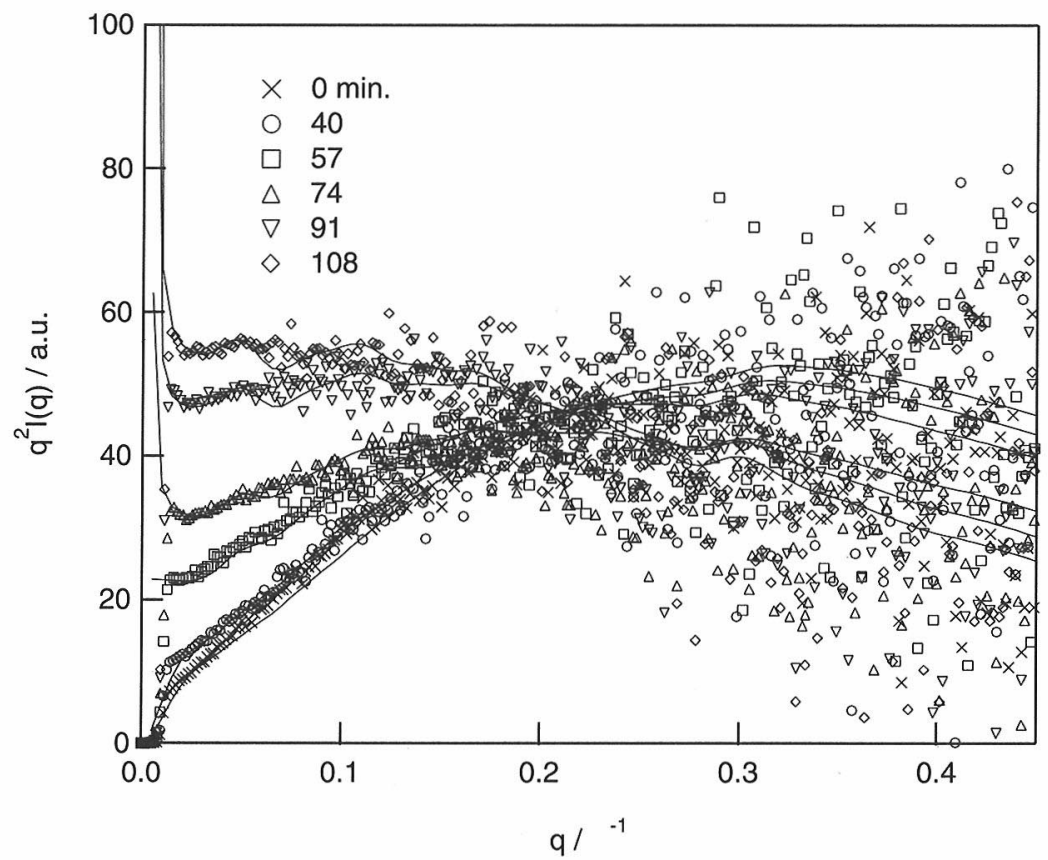

Fig. 13. Observed and calculated scattering profiles at various reaction times (indicated in the figure). Symbols represent the observed small-angle X-ray scattering intensities and solid lines the scattering profiles calculated according to eq. (3) with $A^{2}(q)$ being calculated by assuming a linear combination of two phases of single chains and the domains of 14 parallel stacked chains.

Here $f$ denotes the functionality of the crosslinking domain (the number of branches from a domain), a the conversion (the probability that an arbitrary chosen unit is reacted), $b^{2}$ the mean square average of the distance between the neighboring scattering units and $A^{2}(q)$ the scattering amplitude of each scattering unit (i.e., $A^{2}(q)=1$ in the case of a point). When the scattering unit is composed of a domain of a finite size, $A^{2}(q)$ is given by the scattering factor of the domain(16). In the present example, the domain is considered to be constituted of either an aggregate or a single chain of TSP xyloglucan, so that $A^{2}(q)$ is given by the scattering factors calculated in Fig. 12. When aggregation proceeds, the aggregated domain acts as a polyfunctional group and a tree grows, eventually leading to gelation.

Observed SAXS intensities were analyzed by eq. (3), where $A^{2}(q)$ was assumed to be represented by the scattering factor given by the linear combination of those for a single chain and 14 parallel stacked chains of TSP xyloglucan (see Fig. 11). The gelling system of enzymatically degrading TSP xyloglucan is assumed to be composed approximately of two phases of single chains (dilute phase) and the domains of 14 parallel stacked chains (condensed phase) for computational convenience. In a real system, the condensed phase is supposed to be composed not always of 14 xyloglucan chains but of multiple chains with distribution. However, the scattering from 14 xyloglucan chains reproduces the slight maximum at around $0.5 \mathrm{~nm}^{-1}$ in the observed SAXS profiles, and the fitting results confirm the ad- インから出る分岐数）、a は反応度（任意に選んだ単位が反応し ている確率）、 $b^{2}$ は隣り合う単位間の平均二乗距離、 $A^{2}(q)$ は各 散乱単位の散乱振幅（散乱単位が点の場合は $\left.A^{2}(q)=1\right)$ であ る。散乱単位が有限サイズのドメインで構成される場合、 $A^{2}(q)$ はそのドメインの散乱因子で与えられる(16)。本例では、ドメイ ンはタマリンドキシログルカンの会合体あるいはその一本鎖で 構成されている。従って $A^{2}(q)$ は図 12 に計算された散乱因子 で与えられる。会合が進むと、会合したドメインが多官能性基 として機能し、樹木が生長し、ゲル化に至る。

実測 SAXS プロファイルを（4）式に従って解析したが、 $A^{2}(q)$ は夕マリンドキシログルカン孤立鎖と 14 本鎖並列積層モ デルの線型組み合わせで与えられると仮定した。酵素分解しつ つあるキシログルカンのゲル化系は、一本鎖（希薄相）と 12 本 鎖並列積層ドメイン（濃縮相）の 2 相で構成されると仮定す る。実際の系では、濃縮相は必ずしも 14 本鎖並列積層のみで構 成されているのではなく、分布がある複数鎖並列積層もあるた ろう。しかし 14 本鎖積層モデルは実測 SAXS プロファイルに 現れる $0.5 \mathrm{~nm}^{-1}$ 近傍の小さなピークをよく再現し、図 13 に示す ようにフィッティングの結果はここで仮定したモデルが適正で あることを示唆する。ただしここで注目したいのは、10本以下 の鎖で構成されるドメインモデルから計算した散乱プロファイ ルは、酵素分解の全過程において実測散乱プロファイルとかな り違った傾向を示すことである。ここで仮定したモデルだと、 
Table IV. Evaluated parameters for the tree-like model as a function of reaction time.

\begin{tabular}{|c|l|c|cc|}
\hline $\begin{array}{c}\text { Reaction Time } \\
(\mathrm{min})\end{array}$ & (f-1) $\alpha$ & $\begin{array}{c}\mathrm{b} \\
(\mathrm{nm})\end{array}$ & \multicolumn{2}{|c|}{ Weight fraction of } \\
single chain & 14-chain aggregate \\
\hline 0 & 0.45 & 6.0 & 1.0 & 0.0 \\
40 & 0.5 & 11.0 & 0.49 & 0.51 \\
57 & 1.0 & 13.5 & 0.24 & 0.76 \\
74 & 1.04 & 13.7 & 0.13 & 0.87 \\
91 & 1.06 & 14.0 & 0.07 & 0.93 \\
108 & 1.07 & 14.0 & 0.05 & 0.95 \\
\hline
\end{tabular}

equacy of the present model analysis as shown in Fig. 6. It should be noted here that the domain composed of less than 10 xyloglucan chains fails to yield a satisfactory fitting to the observed SAXS profile. The agreement between observed SAXS profiles and the calculated scattering profiles from the model, is satisfactory over the entire time course of enzymatically degrading reaction. Since no explicit number is known for the functionality $f$ of the domain $(f$ should be equal to 24 if exactly 14 chains are stacked in parallel to constitute a crosslinking domain), $(f-1) \alpha$ is considered as a parameter to specify the average branching degree, where $(f-1) \alpha=1$ indicates a gel point. That is, gelation took place after 57 minutes in the present system. The analysis involves three parameters; $b,(f-1) \alpha$ and the weight fraction of the domain of 14 parallel stacked chains. The evaluated parameters are summarized in Table IV.

As the enzymatic degradation proceeds with time, more domains constituted of about 14 parallel stacked chains are formed, and the branching degree increases. At gel point, about $3 / 4$ of chains are involved in the domains. The distance $b$ between the scattering units increases with reaction time, but reaches an almost constant value after gelation. This result indicates that gelation hinders the enzymatic reaction which takes place mostly on single chains and less on the aggregated chains. When xyloglucan chains aggregate and form the domains (new scattering units), the average distance between the centers of chains/domains becomes larger because the distance between the domains (the condensed phase) is larger than the average distance between two chains in the homogeneous solution. The aggregated chains constitute the condensed phase of a flat plate shape. Although not exactly 14 chains are aligned in parallel, it seems that a single layer of TSP xyloglucan chains forms the domain as confirmed by its thickness $1.1 \mathrm{~nm}$. The domain thus formed seems to serve as a thin wall to constitute a cell-like network.

\section{Acknowledgements}

We acknowledge the long-standing collaboration with Mr. K. Yamatoya and Ms. M. Shirakawa (Dainippon Pharmaceutical Co.) and Dr. Y. Yuguchi ( AIST, Shikoku).
計算散乱プロファイルと実測散乱プロファイルは反応全過程で ほほ良好な一致を示す。ドメインの正確な官能基数は分からな いので（もし 14 本鎖が並列に積み重なっているならば $f=$ 24）、(f-1) $\alpha$ が平均分岐度を表すパラメターであると考える。 $(f-1) \alpha=1$ がゲル点である。ゲル化はこの場合 57 分後に起こっ

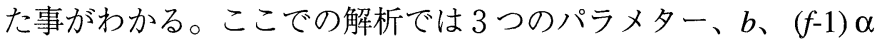
と 14 本鎖積層ドメインの重量分率、が必要である。このパラメ ターの值を表 IVにまとめる。

酵素分解が進行するに従い、より多くの 14 本鎖積層ドメイ ンが形成され、分岐度が増す。ゲル点では約 $75 \%$ の鎖がドメイ ンに含まれることになる。散乱単位間距離 $b$ は反応時間と共に 増加するが、ゲル化後はほぼ一定値となる。この結果は、ゲル 化は酵素反応を妨げ、酵素反応は主として一本鎖の部分で起こ ることを示している。キシログルカン鎖が会合しドメイン（新 たな散乱単位）を形成すると、均質な溶液中の 2 つの一本鎖間 の平均距離よりもドメイン（濃縮相）間の距離のほうが大きい ため、ドメイン・一本鎖の中心間平均距離は長くなる。会合し た鎖は平板な形をした濃縮相を形成する。正確に 14 本の鎖が並 列しているのではないが、厚みが $1.1 \mathrm{~nm}$ であることより、ドメ インはキシログルカン鎖一層であると考えられる。このように 作られたドメインは細胞状網目を構成する薄い壁として機能す るようである。

謝 辞

大和谷和彦氏、白川真由美氏（以上大日本製薬(株)）、湯口 宣明氏（産業技術総合研究所四国センター）の長年にわたる共 同研究に対して感謝の意を表します。 


\section{References}

1. W. S. York, H. van Halbeek, A. G. Darvill, and P. Albersheim, Carbohydr. Res., 200, 9 (1990)

2. Q. Wang, P. R. Ellis, S. B. Ross-Murphy, J. S. G. Reid, Carbohydr. Res., 284, 229 (1996)

3. U. A. Onyechi, P. A. Judd, P. R. Ellis, Proc. Nutr. Soc., 52, 388 (1993)

4. P. Lang, and K. Kajiwara, J. Biomater. Sci., 4, 517 (1993)

5. H. Yamakawa, Helical Wormlike Chains in Polymer Solutions, Springer Verlag, Berlin, 1998

6. Guenet, J-M. Thermoreversible Gelation of Polymers and Biopolymers; Academic Press: London (1992)

7. Y. Yuguchi, M. Mimura, H. Urlakawa, K. Kajiwara, M. Shirakawa, K. Yamatoya, S. Kitamura, Proc. Intern. Workshop Green Polym., p.306, Bandung-Bogor, Indonesia, 1996

8. M. Mimura, H. Urakawa, K. Kajiwara, S. Kitamura, K. Takeo, Macromol. Symp., 99, 43 (1995)

9. S. Levy, W. S. York, R. Stuike-Prill, B. Meyer, and A. L. Staehelin, Plant J., 1, 195 (1991)

10. Q. Wang, P. R. Ellis, S. B. Ross-Murphy, W. Burchard, Carbohydr. Polym., 33, 115 (1998)

11. M. Dentini, P. Allegrini, Y. Yuguchi, M. Mimura, H. Urakawa, V. Crescenzi, W. Burchard, K. Kajiwara, Macromolecules, to appear

12. P. Lang, K. Kajiwara, and W. Burchard, Macromolecules, 26, 3992 (1993)

13. M. Shirakawa, K. Yamatoya, K. Nishinari, Food Hydrocoll., 12, 25 (1998)

14. See, for example, P. J. Flory, Principles of Polymer Chemistry, Cornell U.P. (1953)

15. K. Kajiwara, S. Kohjiya, M. Shibayama, H. Urakawa, in Polymer Gels: Fundamentals and Biomedical Applications, pp. 1, (ed. By D. DeRossi, K. Kajiwara, Y. Osada, A. Yamauchi), Plenum (1991)

16. K. Kajiwara, Kobunnshi, 48, 396 (1999)

Received on September 18, 2002, accepted on November 14, 2002

\section{Profile of the Authors}

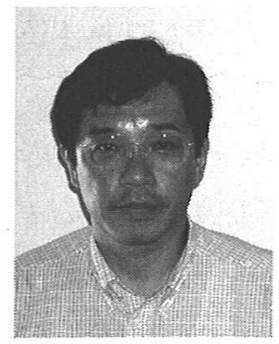

Hiroshi Urakawa was born in 1955. He graduated from Kyoto Institute of Technology, Faculty of Engineering and Design at 1978, and received his $\mathrm{Ph}$. D degree from Kyoto University in 1986. He worked as research assistant and is now working as associate professor of Kyoto Institute of Technology. His mejor is physical chemistry of polymers, and also physical chemistry of dyeing.

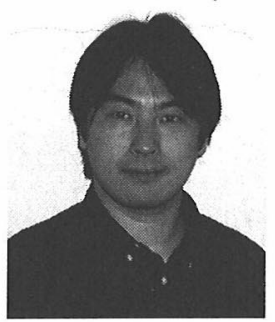

Mitsuru Mimura was born in 1967. He graduated from Kyoto Institute of Technology, Faculty of Engineering and Design in 1991, and received his $\mathrm{Ph}$. D degree in 1997. He is working as temporary lecturer at Kyoto Institute of Technology. His research interest is forcused on the structural properties of poly- and oligosaccharides.

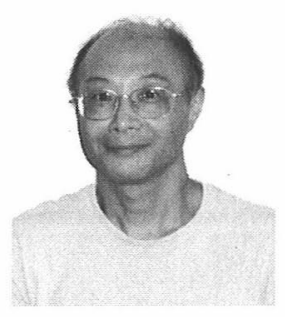

Kanji Kajiwara was born in 1940. He gradeated from Kyoto University, Faculty of Engineering in 1963, and received his $\mathrm{Ph}$. D degree from Essex University in 1968. He worked as research assistant at Kyoto University(1985-1988), and moved to Kyoto Institute of Technology as assistant professor and as professor (1988-2002). Now he is professor at Faculty of Home Economics at Otsuma Women's University. His major is physical chemistry of polymers. 